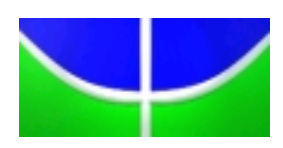

UNIVERSIDADE DE BRASÍLIA

CET - Centro de Excelência em Turismo

Pós-graduação Lato Sensu

Curso de Especialização em Gestão de Negócios em Turismo

\title{
MERCADO TURÍSTICO DE BRASÍLIA E SUA PRINCIPAL VOCAÇÃO TURÍSTICA
}

\section{WEIDER DANIEL LEMES}

Professor orientador: Doutor Gilson Zehetmeyer Borda

Brasília - 2009 


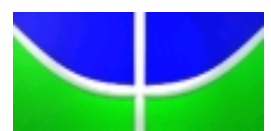

UNIVERSIDADE DE BRASÍLIA

CET - Centro de Excelência em Turismo

Pós-graduação Lato Sensu

Curso de Especialização em Gestão de Negócios em Turismo

\section{MERCADO TURÍSTICO DE BRASÍLIA E SUA PRINCIPAL VOCAÇÃO TURÍSTICA}

\section{WEIDER DANIEL LEMES}

Orientador: Prof. Dr. Gilson Zehetmeyer Borda

Monografia apresentada ao Centro de Excelência em Turismo da Universidade de Brasília - CET UnB, como requisito inicial à obtenção do Grau de Especialista em Gestão de Negócios em Turismo

Brasília - 2009 
Lemes, Weider Daniel

Mercado turístico de Brasília e sua principal vocação turística, Lemes-Weider Daniel. - Brasília, 2009.

xvi, 57 f. : il.

Monografia (Gestão de Negócios em Turismo) - Universidade de Brasília, Centro de Excelência em Turismo, 2009.

Orientador: Gilson Zehetmeyer Borda.

1. Turismo. 2. Turismo de Eventos e Negócios. 3. Trade Turístico. I. Título. II. Título: uma revisão. 


\section{UNIVERSIDADE DE BRASÍLIA \\ CET - Centro de Excelência em Turismo \\ Pós-graduação Lato Sensu}

Curso de Especialização em Gestão de Negócios em turismo

Monografia apresentada ao Centro de Excelência em Turismo da Universidade de Brasília CET - UnB, como requisito inicial à obtenção do Grau de Especialista em Gestão de Negócios em Turismo

\section{MERCADO TURÍSTICO DE BRASÍLIA E SUA PRINCIPAL VOCAÇÃO TURÍSTICA}

\section{Weider Daniel Lemes}

Aprovado por:

Professor orientador: Gilson Borda, Dr.

Professor Avaliador: Domingos Sézia, Msc.

$\overline{\text { Professor Avaliador: Walter Ribeiro, Msc. }}$

Brasília, 28 de julho de 2009 
Dedico esse trabalho a toda minha família e amigos, em especial a minha querida mãe Ana Maria Resende e meu Pai Nivaldo Rocha Lemes, que sempre me ajudaram e me apoiaram a continuar meu aperfeiçoamento profisssional. 
Agradeço a Deus pelo dom da vida e sabedoria, agradeço à minha querida mãe, ao meu pai e amigos, em especial minha amiga Flávia Stella, que sempre me deu muita força e estava sempre ali me escutando e me apoiando na realização desse trabalho e por sua imensa paciência nos momentos de stress, aos meus grandes amigos, que me compreenderam e me alegraram nos momentos difíceis, aos novos amigos que fiz, ao meu querido orientador Gilson e a todos que me ajudaram na finalização desse trabalho. Agradeço imensamente pelo o apoio e dedicação de cada um. 


\section{RESUMO}

Este trabalho foi realizado com a expectativa de conhecer e aprofundar no mercado turístico de Brasília, em especial o mercado de eventos e negócios, uma vez que é o segmento que tem recebido grande destaque no mercado brasileiro e mundial. O estudo teve uns dos principais objetivos analisar a opinião do trade turístico quanto a principal vocação turística da cidade de Brasília. Para estruturar o trabalho, o autor delineou a história e as características do turismo de eventos como elemento essencial na atividade turística atual; discutiu sobre a atividade turística e suas questões contemporâneas; alguns aspectos importantes do sistema de turismo, da segmentação turística e da gestão estratégica dos destinos turísticos. Foi também apresentado o panorama turístico da cidade de Brasília, incluindo sua história, atrativos, aspectos sobre o turismo de eventos e negócios, suas deficiências, novos projetos e investimentos que serão realizados na capital federal. Em um segundo momento, foram apresentados os procedimentos metodológicos utilizados no trabalho e, por fim, para um melhor delineamento do estudo, foram aplicados questionários estruturados, com questões fechadas e objetivas junto ao trade turístico da cidade e análise das pesquisas e trabalhos já realizados sobre o tema, os quais foram de grande importância, pois possibilitou maior interação e observação do mercado estudado. Com isso, foi identificado que o turismo em Brasília está passando por um momento de amadurecimento, pois levantou-se a existência de vários projetos para melhoraria ad infraestrutura da cidade e para estruturar o turismo, assim como várias deficiências a serem sanadas e que o trade turístico ainda tem uma visão um pouco distorcida sobre o turismo na capital, acreditando que turismo de eventos é a principal vocação turística na cidade, o que na verdade é o turismo de negócios, a que se deve a existência do turismo na capital.

Palavras-chave: Turismo, Turismo de Negócios e Eventos e Trade Turístico 


\begin{abstract}
This study was conducted with a high expectation of exploring and deepening the knowledge about tourism in Brasilia, more specifically the tourism associated with events and business, since this area had become very important to the Brazilian and international market. The main objective of this study was to analyze the opinion of the touristic trade relative to the main touristic nature of Brasilia. For a better structuring of this work, I outlined the history and characteristics of the tourism related with events as an essential element in the current tourist activity; some important aspects of the tourism system are discussed relative to touristic activity and contemporary issues, the segmentation and the strategic management of tourism destinations. Additionally, I also present the touristic landscape of Brasilia, including its history, attractions, potential for events and business tourism, its deficiencies, new projects and investments in the Federal Capital. In a second point, I present the methodological procedures used in this study, and finally, for a better organization of the study, I applied structured and objective questionnaires to the touristic trade of this city and analyzed research and studies already conducted on this subject. These latter points were of great importance, allowing greater interaction with and observations of the studied market. Based on the study, it was possible to conclude that the tourist industry in Brasilia is going through a moment of attaining greater maturity. It was possible to observe the existence of various projects to improve the infrastructure of the city and to structure the touristic trade, as well as several problems that have to be resolved. The touristic industry still maintains the somewhat distorted idea about tourism in the capital, believing that the tourism associated with events is the main touristic vocation of the city.
\end{abstract}

Keywords: Tourism, Tourism of Events and business e touristic trade 


\section{LISTA DE TABELAS}

Tabela 01 - Estratégias e táticas de diferenciação

Tabela 02 - Motivos da viagem para o Distrito Federal 50

Tabela 03 - Principal motivo da viagem ao DF 51

Tabela 04 - Avaliação geral da satisfação do turista de negócios 62

Tabela 05 - Taxa de ocupação dos hotéis da cidade de Brasília 73 


\section{LISTA DE QUADROS}

Quadro 01 - Classificação dos eventos por tipologia ....................................... 37 


\section{LISTA DE QRÁFICOS}

Gráfico 01 - Grau de escolaridade dos entrevistados 76

Gráfico 02 - Área do trade que o entrevistado atua ............................................. 76

Gráfico 03 - Tipo de turista que Brasília mais recebe ........................................ 78

Gráfico 04 - A principal deficiência na infraestrutura de eventos de BSB ............. 79

Gráfico 05 - Principal vocação turística de Brasília .............................................. 80

Gráfico 06 - Integração do trade turístico de Brasília ........................................... 81

Gráfico 07- A principal dificuldade para que Brasília se destaque como destino ..... 83 


\section{SUMÁRIO}

1. INTRODUÇÃO 14

1.1. Contextualização do Tema 14

1.2. Delimitação do Tema 15

1.3. Descrição da Situação Problemática 15

$\begin{array}{ll}\text { 1.4. Justificativa } & 16\end{array}$

$\begin{array}{ll}\text { 1.5. Hipóteses } & 17\end{array}$

$\begin{array}{ll}\text { 1.6. Objetivo Geral } & 18\end{array}$

$\begin{array}{ll}\text { 1.7. Objetivo Específico } & 18\end{array}$

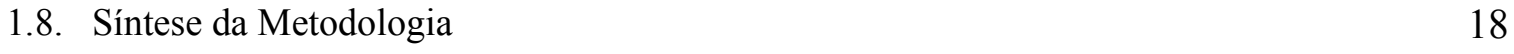

1.9. Organização e Estrutura do Trabalho 19

2. REVISÃO DE LITERATURA 20

2.1. Turismo e questões contemporâneas 20

2.1.1. Sistema do Turismo 22

2.1.2. Segmentação do Mercado Turístico 25

2.1.3. Gestão Estratégica de Destinos Turísticos no Mundo Globalizado 29

2.2. Turismo de Eventos e Negócios 33

2.2.1. Turismo de Eventos e suas características 33

2.2.2. Característica básicas do Turista de eventos e negócios 39

2.2.3. A Importância do Turismo de eventos e Negócios e seus impactos no destino 41

2.3. Panorama Turístico de Brasília 43

2.3.1. História de Brasília 43

2.3.2. Principais Atrativos da Distrito Federal e entorno 45

2.3.3. Turismo de Eventos e Negócios em Brasília $\quad 50$

2.3.4. Novos Projetos e investimentos na Capital do Brasil 57

2.3.5. Perfil dos Turistas de Eventos e Negócios de Brasília 59

3. METODOLOGIA 65

3.1. Caracterização da Pesquisa 65 
3.2. Definição do universo da Pesquisa 66

$\begin{array}{ll}\text { 3.3. Procedimentos de coleta de dados } & 67\end{array}$

3.4. Plano e instrumento de coleta de dados 68

3.5. Plano de análise de dados 68

$\begin{array}{ll}\text { 3.5.2. Questionário } & 68\end{array}$

4 . ANÁLISE DOS RESULTADOS DA PESQUISA

4.1 Análise dos dados secundários $\quad 71$

$\begin{array}{ll}\text { 4.2 Análise dos dados primários } & 74\end{array}$

5. CONSIDERAÇÕES FINAIS

6. REFERÊNCIAS

$\begin{array}{ll}\text { 6.1 Bibliográficas } & 87\end{array}$

6.2 Mídias e endereços eletrônicos consultados: $\quad 90$

7. APÊNDICE

7.1. Instrumento de Coleta de dados 93 


\section{INTRODUÇÃO}

\subsection{Contextualização do tema:}

Da vontade de aprofundar o conhecimento no âmbito do mercado turístico da Capital Federal, de sua vocação turística, estudar e analisar seus atrativos, infraestrutura, pontos fortes e fracos, e em especial o seu mercado de eventos e negócios, que de acordo com o Ministério do Turismo" "compreende um conjunto de atividades turísticas decorrentes dos encontros de interesse profissional, técnico, científico e social”, foi que o presente projeto nasceu, pois começa-se a observar cada vez mais pessoas viajando não só com o intuito de relaxar, mas também em busca de novas oportunidades de negócios e aperfeiçoamento intelectual.

O mercado de turismo de negócios e eventos está em franco desenvolvimento no Brasil e no mundo. Devido a esse aumento sem precedentes da concorrência global, que antes se concentrava quase que exclusivamente nos Estados Unidos e na Europa, os novos destinos se vêem obrigados a investir em infraestrutura e em mão de obra especializada para o setor de turismo.

De acordo com a ICCA - International Congress \& Convention Association - a promoção de eventos é responsável, direta e indiretamente, por aproximadamente $11 \%$ do PIB mundial (US\$ 27 bilhões). O gasto por participante fica na média de R \$ 680,00 (seiscentos e oitenta reais). O Brasil já está entre os principais países receptores de eventos internacionais do mundo, ocupando o segundo lugar no Continente Americano, perdendo apenas para os Estados Unidos (BAHL, 2003).

Nos últimos anos tem se ouvido muito que Brasília é a capital de eventos do Brasil, sendo esse, inclusive, o slogan utilizado atualmente pelo Ministério do Turismo e a Brasiliatur (Empresa Brasilense de Turismo) em seus sites, para divulgar o destino e atrair novos turistas, oportunidades de negócios e eventos. Demonstra-se aqui, uma tentativa de fixar uma identidade turística própria para a Capital, ao mesmo tempo em que se percebe um maior investimento em equipamentos turísticos como hotéis, centros de convenções e um aumento considerável de empresas organizadoras e promotoras de eventos na cidade.

\footnotetext{
${ }^{1}$ MINISTERIO DO TURISMO, Segmentação do turismo disponível em: http://www.mda.gov.br/saf/arquivos/0708519758.pdf acesso em 09/04/09
} 
Sendo assim, o estudo sobre a vocação turística de Brasília, que é o principal foco do presente projeto, vem num momento oportuno, buscando correlacionar o turismo de eventos e negócios com a real vocação turística da cidade.

Esse estudo, sobre o mercado turístico de Brasília, proporcionou ao autor uma maior concepção da real vocação turística desta Capital, onde foram evidenciadas suas potencialidades, seu principal público receptor turístico, suas principais deficiências em infraestrutura, dentre outros fatores que influenciam diretamente na formação da vocação turística de um determinado destino.

E foi a partir daí que se percebeu a necessidade de se fazer uma pesquisa de campo, em especial com o público do trade turístico da cidade de Brasília, na qual foram levantados adicionalmente dados e informações em trabalhos, pesquisas, monografias, artigos e reportagens relativos ao assunto.

Segundo Duarte (1996, p.27), trade turístico é uma visão mercadológica que constitui a primeira oportunidade do administrador entender seus equipamentos e possuir uma ferramenta para definir as reais possibilidades de retorno que poderá obter dos vários mercados consumidores. Empresas hoteleiras (hospedagem), transporte turístico, agências de viagens e turismo, são alguns exemplos de empresas que compõem esse trade.

\subsection{Delimitação do tema}

A vontade de conhecer, entender o mercado turístico de Brasília, levantar suas potencialidades e problemáticas e de ter uma maior especialidade na área estudada fez despertar o interesse nesse tema, com o intuito de levantar dados oportunos e relevantes para a cidade e seus administradores, por meio da opinião do próprio trade, quanto à real vocação turística da cidade e suas singularidades.

\subsection{Descrição da Situação Problemática}

O turismo de negócios e de eventos de Brasília se mostra como um dos principais focos da Administração Pública e privada, sendo muito aclamado principalmente o de eventos como a 
principal vocação turística da cidade. A partir dessa percepção se viu a necessidade de entender e fazer um estudo sobre esse mercado turístico da capital. Em especial o de turismo de eventos e negócios, levantando a opinião do trade sobre a vocação turística da cidade e suas problemáticas e as análises de pesquisas e trabalhos já realizados anteriormente sobre o tema.

Com isso, surge o problema de pesquisa: Qual a percepção do trade quanto à vocação turística de Brasília?

\subsection{Justificativa}

Para qualquer cidade que possui atrativos significativos ou pontecialidades turísticas é necessário um estudo sobre seu mercado turístico, ou seja, de sua vocação turística. No caso de Brasília, levantar sua vocação turística possibilitará, aos órgãos públicos e às empresas privadas do ramo, expertise para tornar Brasília mais competitiva frente ao mercado turístico nacional e internacional, além de aprimorar e aperfeiçoar suas fraquezas, tomar decisões acertadas e se tornar um destino turístico diferenciado e atrativo para seu público alvo.

O Fenômeno "Turismo" é um dos setores da economia mundial que mais cresce nos últimos anos e o Turismo de eventos, segundo (BAHL, 2003, pg. 4) Eventos: A importância para o Turismo do Terceiro Milênio, é um segmento que possui características únicas e possui alguns pontos relevantes, conforme segue abaixo:

- É uma área pouco atingida em época de crise;

- Não depende do regime governamental;

- Gera divisas e empregos diretos e indiretos;

- Motiva investimentos e melhorias (Centros de Convenções, hotéis, restaurantes etc.)

- Não é influenciada pela sazonalidade da atividade turística;

- Atinge e traz benefícios para todos os outros segmentos do turismo. 
O Ex. Presidente da Brasíliatur, César Gonçalves, em entrevista ao Jornal do Brasil², afirmou que Brasília, com pouco mais de 45 anos, é o terceiro maior pólo gastronômico e hoteleiro do Brasil, perdendo apenas para São Paulo e Rio. Disse que Brasília ao ganhar dois centros de eventos importantíssimos, Ulisses Guimarães e Brasil XXI, se consolidou como um dos principais pólos de turismo de eventos do Brasil. Comenta que Brasília ainda possui uma cultura diversificada, formada por pessoas de diversas regiões do Brasil, o que acaba influenciando na formação da cultura e nos costumes locais, como, por exemplo, a criação do Clube do Choro, que já é uma das características da cidade. Informa, também, que Brasília possui cerca de 100 mil pessoas trabalhando com hospedagem.

Levando-se em conta o investimento que vem sendo feito na infraestrutura turística de Brasília, a maior preocupação por parte dos órgãos dirigentes da área e o crescimento do turismo de eventos e negócios no Brasil e no mundo, que se viu a importância de realizar esse trabalho. Para entender melhor a dinâmica do mercado turístico da cidade, em especial o de turismo de eventos e negócios.

Além disso, a realização dessa pesquisa possibilitou a atualização de trabalhos e projetos já realizados, enriquecendo os estudos sobre o tema, possibilitando também maior entendimento sobre o funcionamento da atividade turística na capital do país, pontos fortes e fracos do turismo e infraestrutura em geral, os quais poderão proporcionar aos órgãos públicos e empresas do trade, maior reflexão sobre as carências e potencialidades da cidade e, porque não, ferramentas para desenvolver um trabalho mais focado, que certamente ocasionaria um êxito maior em suas próximas investidas no mercado turístico.

\subsection{Hipóteses}

Hipótese Positiva: A maioria do trade percebe como vocação de Brasília: Turismo de Eventos e Negócios

Hipótese Negativa: A maioria do trade não percebe como vocação de Brasília: Turismo de Eventos e negócios

\footnotetext{
${ }^{2}$ Entrevista disponível em: http://cetunb.tempsite.ws/index.php?option=com_content\&task=view\&id=502 Acesso em 15/12/2008
} 


\subsection{Objetivo Geral}

Fazer um estudo sobre o turismo em Brasília, visando identificar a vocação turística da cidade, baseado na percepção do trade.

\subsection{Objetivos Específicos}

Levantar as ações, projetos e planos a serem executados pela iniciativa pública e privada para alavancar Brasília como destino turístico e suas atuais deficiências;

Analisar o perfil do turista e o turismo de Brasília por meio dos dados contidos na Pesquisa Perfil do Turista de Brasília - Estudo realizado pelo CET - Centro de Excelência em Turismo - UNB em parceria com a Brasíliatur no ano de 2008;

Identificar os segmentos turísticos mais representativos na Capital Federal por meio da Pesquisa Indicadores Econômicos para o planejamento do turismo do Distrito Federal Estudo realizado pelo CET - Centro de Excelência em Turismo - UNB em parceria com a Brasiliatur nos anos de 2007 e 2008 e da pesquisa de campo com o trade turístico da cidade aplicada pelo autor.

\subsection{Síntese da Metodologia}

Para a realização do estudo em questão foram utilizados os métodos de pesquisas bibliográficas em artigos, periódicos, internet, revistas, jornais e de pesquisa documental junto aos órgãos, associações, instituições e centros de estudos relacionados ao assunto tratado.

Posteriormente, utilizou-se dados dispostos em quadros e gráficos para auxiliar na interpretação das informações, empregando-se o método dedutivo de pesquisa. Foi feita uma pesquisa quantitativa com amostra intencional, coletando-se dados por meio de um questionário composto por 8 perguntas objetivas, o qual foi aplicado ao trade turístico da cidade, especificamente aos gestores de hotéis, restaurantes, agências de viagens, eventos, universidade, companhias aérea, receptivos, órgãos públicos (Brasíliatur, Embratur e Ministério do Turismo) e instituições do setor (ABIH - Agência Brasileira da Indústria Hotéis 
de Brasília, SEBRAE, CVBDF - Brasília Convention \& Visitors Bureau e ABEOC Associação Brasileira de Empresas de Eventos)

A coleta de dados ocorreu no período compreendido pelo mês de maio e o início do mês de junho de 2009 e a partir do levantamento dos dados qualitativos e dos 106 questionários respondidos, realizou-se as análises qualitativa e quantitativa das informações levantadas. Houve a análise qualitativa devido aos dados extraídos em trabalhos e pesquisas realizados anteriormente sobre o tema e qualitativa porque foi feita a pesquisa de campo.

\subsection{Organização e Estrutura do Trabalho}

Seguindo a metodologia descrita, o trabalho foi subdividido em cinco capítulos, para maior compreensão da proposta.

O primeiro capítulo traz informações gerais sobre o tema, objetivos, problema e hipótese.

O segundo capítulo aborda a revisão da literatura ligada ao tema.

No terceiro capítulo foi desenvolvida a metodologia utilizada no estudo.

No quarto capítulo foi feita a análise dos dados primários e secundários coletados durante o desenvolvimento da pesquisa e no quinto capítulo foram apresentadas as conclusões relativas aos objetivos, ao problema e às hipóteses. 


\section{REVISÃO DE LITERATURA}

\subsection{Turismo e questões contemporâneas}

O Turismo, hoje, no século XXI, é encarado, ao mesmo tempo, como um fenômeno econômico e social, pois tem capacidade de produzir variados bens e serviços com o intuito de satisfazer as mais diversas necessidades.

A viagem e o deslocamento é algo intrínseco ao sentido etimológico da palavra turismo que vem de "tour", no Francês: viagem em circuito: deslocamento de ida e volta. Porém, somente no século XVIII com os Ingleses que a palavra Tourism, Tourist foi criada. Assim, devido à sua própria origem que não existe turismo sem deslocamento. (BENI, 2007)

De acordo com a Organização Mundial do Turismo OMT o turismo é considerado como uma atividade que as pessoas realizam durante suas viagens e estadas em lugares diferentes do de sua moradia habitual, por um período de tempo contínuo inferior a um ano, com fins de lazer, por negócios ou outros motivos, não relacionados com o exercício de uma atividade remunerada no lugar visitado (DIAS, 2008, p.24),

Em um sentido mais geral, o termo turismo pode ser conceituado como:

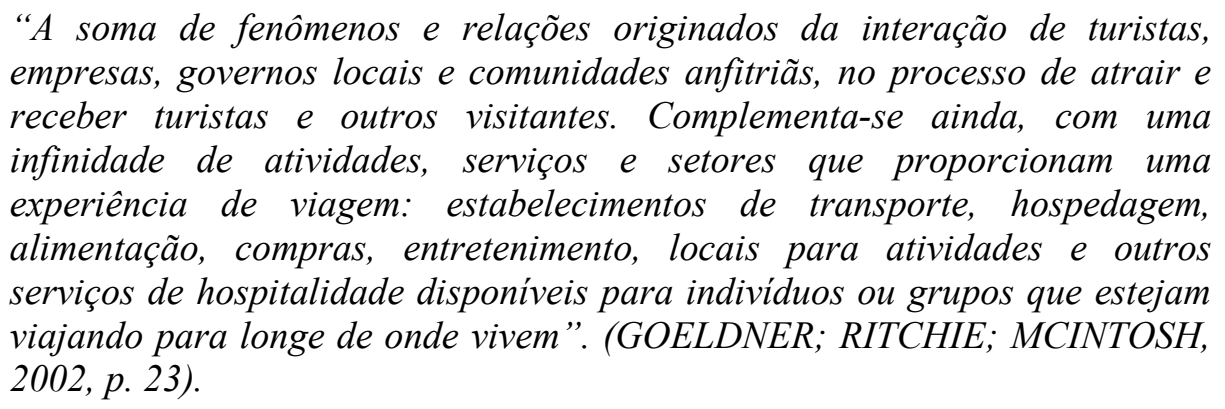

Em outra visão mais holística e acadêmica, o autor Jafar Jarai (aput, BENI, 2007, p.36) define turismo como:

"É um estudo do homem longe de seu local de residência, da indústria que satisfaz suas necessidades, e dos impactos que ambos, ele e a indústria, geram sobre o ambiente físico, econômico e sociocultural da área receptora."

Já numa visão um pouco filosófica, porém instigante, a pesquisadora Marutscha Martini Moesch (2002, p. 41) define:

"O Turismo como num fenômeno sociocultural de profundo valor simbólico para os sujeitos que o praticam. Em seu ponto de vista, o sujeito turístico consome o Turismo, por intermédio de um processo tribal, de comunhão, de 
realização, de testemunho, em um espaço e tempo real como virtual, desde que possivel de convivência, de presenteísmo. O valor simbólico perpassado pela comunicação táctil desse fenômeno, reproduz-se, ideologicamente, quando os turistas comungam de sentimentos, reproduzidos pela diversão, $e$ quando há possibilidade de materialização do imaginário, por vezes individual em societal".

Através dessas diferentes perspectivas frente aos conceitos sobre o turismo, nota-se uma pequena unicidade entre os autores no ponto em que entendem que o indivíduo busca novas experiências, sensações fora do seu habitat natural, ou seja, viagens que podem ser em destinações próximas a sua localidade, outro estado, país ou mesmo continente. Contudo essa busca pelo novo e exótico, vai muito além de uma visita e experiências diversas (lazer ou negócios), ela movimenta uma cadeia produtiva enorme, assim como expectativas diferentes, necessidades latentes e consequências diversas, como impactos, positivos ou negativos. Tais conseqüências devem ser analisadas e estudadas de forma consciente, estruturadas e planejadas, para que o turismo se desenvolva de forma sustentável, englobando todos os agentes envolvidos. Por isso a segunda definição de Jafar Jarai é a mais apropriada para esse trabalho, pois tenta englobar de certa forma quase todos os agentes envolvidos na atividade e seus impactos na área receptora.

De acordo com dados da OMT (Organização Mundial de Turismo, 2000), a Indústria do turismo pode ser considerada entre as mais importantes atividades econômicas mundiais, responsáveis por 192,2 milhões de empregos, número que deverá aumentar para 251,9 milhões até o ano de 2010 (BAHL, 2003).

A WTTC (World Travel and Tourism Council - 2000), diz que o setor de viagens e turismo corresponde a $10,9 \%$ do PIB mundial e já responde por $10 \%$ dos gastos dos consumidores em todo o mundo, com uma arrecadação de U\$ 350 milhões em impostos, perdendo somente para a indústria alimentícia (DIAS, 2008).

Por ser o Turismo hoje - na era moderna - um fenômeno que envolve vários fatores sociais, culturais, econômicos e ambientais, não se pode deixar de abordar aqui nesse trabalho seus impactos positivos e negativos nos destinos turísticos.

Beni (2007, pg.39), destaca que o turismo é um eficiente meio para:

- $\quad$ Promover a difusão de informação sobre uma determinada região ou localidade, seus valores naturais, culturais e sociais; 
- Abrir novas perspectivas sociais como resultado do desenvolvimento econômico e cultural da região;

- Integrar socialmente, incrementar (em determinados casos) a consciência nacional;

- Desenvolver a criatividade em vários campos;

- $\quad$ Promover o sentimento de liberdade mediante a abertura ao mundo, estabelecendo ou estendendo os contatos culturais, estimulando o interesse pelas viagens turísticas.

Em contra partida, o destino visitado, pode sofrer os seguintes impactos (BENI, 2007, p.39):

- Degradação e destruição dos recursos naturais;

- Perda autenticidade da cultura local;

- Descrição estereotipada e falsa do turista e do país ou região de que procede, por falta de informação adequada;

- Ausência de perspectivas dos grupos da população local, das áreas de destinação turística, que não obtêm benefícios diretos das visitas dos turistas ou do próprio sistema de turismo da localidade;

- Aparecimento de fenômenos de desintegração da comunidade;

- Dependência do capital estrangeiro ou de estereótipos existentes em face do turismo.

Todavia, o sucesso de um destino está ligado intrinsecamente ao seu planejamento consciente, englobando todo o sistema do turismo: Ecológico, social, econômico e cultural, ou seja, sem o envolvimento da comunidade, distribuição de tarefas, distribuição do lucro, cuidado e manejo do meio, preservação da cultura, treinamento da comunidade e respeito uns com os outros. $\mathrm{O}$ fenômeno estará fadado aos impactos descritos no parágrafo anterior.

\subsubsection{Sistema do Turismo}

Nos últimos tempos começou-se a lançar um novo olhar sobre o turismo, relacionando-o à aplicação da teoria geral dos sistemas. Assim, ele pode ser visto como um sistema que 
compõe partes diferenciadas interligadas umas com as outras, formando um todo organizado que possui uma finalidade, um objetivo constante. (BENI, 2007)

Destaca-se ainda a importância da teoria geral do sistema turismo por estabelecer bases conceituais para a organização de conhecimentos interdisciplinares, podendo estabelecer e identificar componentes e sua interação com um fenômeno. No caso turismo e também suas funções, relações e interação deste com o seu ambiente. E enxergando o turismo nos moldes da ótica da teoria geral dos sistemas, pode-se caracterizá-lo, em seu conjunto, como um sistema aberto, composto basicamente por cinco elementos: um dinâmico (o turista), três geográficos (a região geradora, a rota de trânsito e a região de destino); e um elemento econômico, constituído pela indústria turística. (ACERENZA, 2002)

O sistema turístico passa a ter cada vez mais importância na sociedade moderna e esta pode ter tantas subdivisões quanto forem necessárias em função do estudo proposto. (DIAS, 2008)

O sistema turismo pode ser subdividido em sistemas menores para sua compreensão, considerando os sistemas: do mercado, da oferta, da produção, da distribuição, da demanda e do consumo. (BENI, 2007)

De toda forma entende que devemos entender o turismo como um sistema de relações amplas que apresenta interações ambientais, econômicas, jurídicas, sociais, políticas, ecológicas, tecnológicas entre outros (Dias, 2008)

Devido a isso que os estudiosos, empresários e profissionais da área devem ter uma visão holística do todo turístico, trabalhar em conjunto com profissionais das mais diversas áreas, utilizando as diferentes fontes de conhecimento, para explicar, entender e empreender esse fenômeno multidisciplinar que é o turismo.

Uma vez definido o sistema do turismo, na visão de diferentes autores, faz-se imprescindível a identificação dos subsistemas, que nada mais são que os componentes do sistema que forma o todo maior, a perceber no próximo parágrafo.

Cuervo (apud ACERENZA, 2002, p. 196) identificou os seguintes subsistemas dentro desse grande sistema chamado turismo:

- Os transportes, em todas as suas formas; 
- Os alojamentos, também em todas as suas formas;

- Os serviços de alimentação, em toda sua gama;

- Os centros de lazer e diversão;

- Os estabelecimentos comerciais relacionados;

- Os serviços complementares, tais como agências de viagens, guias de turismo, empresas que alugam automóveis, etc.

Conforme relatado nos parágrafos anteriores o sistema turismo envolve vários subsistemas, é um fenômeno multidisciplinar e para que o mesmo ocorra faz-se importante destacar suas principais motivações, que são várias, porém iremos abordar as principais no parágrafo a seguir.

Segundo Acerenza (2002, p. 203-205) os motivos que dão origem ao turismo convencional ou de lazer, normalmente estão relacionados com aspectos culturais, descanso, prazer ou recreação, sendo assim foram classificados da seguinte forma:

- Necessidade de relaxamento e recuperação corporal

- Desejo de praticar algum tipo de esporte

- Expectativas de prazer e diversão

- Interesse em conhecer lugares diferentes

- Relações interpessoais

- Prestígio e status pessoal

- Motivos que dão origem ao turismo especializado: expectativas de emoção e aventura, interesse científico.

- Motivos que dão origem ao turismo de afinidade ou interesse comum: propósitos espirituais, razões profissionais ou de negócios. 
Enfim, compreende-se o sistema turismo como um fenômeno totalmente multidisciplinar, por envolver diversas disciplinas do conhecimento científico (Antropologia, Sociologia, Psicologia, Psicologia Social, Geografia, Urbanismo, Economia, Política, Administração, Direto etc.), o qual pode gerar impactos, positivos e/ou negativos na economia, na cultura e no ambiente onde ele está inserido. E é devido a essa complexidade e amplitude do sistema turismo, que se deve levar em conta sua real importância para a sociedade atual, sendo o mesmo uma ferramenta importante e também alternativa para destinos com potenciais turísticos e carentes de empregos. Utilizando o turismo, essas comunidades podem se desenvolver, preservando suas raízes e sendo utilizados em prol de todo o meio em que está inserido e não de forma predadora, beneficiando apenas uma parcela da sociedade. Somente através de atitudes como essa que os destinos poderão ser mais sustentáveis e ter mais longevidade para as próximas gerações.

\subsubsection{Segmentação do Mercado Turístico}

Como vivemos numa sociedade heterogênea, estressante, com grande acesso a informações, aumento do tempo livre, facilidades cada vez maiores para viajar, como financiamento e diminuição dos preços das passagens, as pessoas acabaram sendo impulsionadas a buscar novas experiências e sensações em diferentes destinos e atrações.

É seguindo essas mudanças mercadológicas, originadas basicamente em função dos atrativos dos destinos, que a segmentação ocorre naturalmente ou de forma planejada. Pois, segmentação nada mais é do que uma forma de tentar organizar e gerir o mercado. Estas gestão e organização são feitas por meio do enfoque na demanda, identificando certos grupos de consumidores, com particularizações que determinam suas decisões, preferências e motivações. Já os produtos, roteiros turísticos em geral são estabelecidos de acordo com a oferta (em relação à demanda), de modo a caracterizar segmentos ou tipos de turismo específicos, porém, isso não significa que um produto só pode apresentar e oferecer atividades relacionadas a apenas um segmento de oferta ou demanda, uma vez que novas denominações surgem o tempo todo, em decorrência da incessante dinâmica das pessoas e mercados, na busca de novas experiências, aliada às novas tecnologias e à criatividade das operadoras turísticas (MINISTÉRIO DO TURISMO, 2009)³.

\footnotetext{
${ }^{3}$ MINISTÉRIO DO TURISMO, segmentação do turismo disponível em: http://institucional.turismo.gov.br/arquivos_open/diretrizes_manuais/cadernos_manuais/Segmentaxo_Turismo
} 
Por outro lado, o mercado atual tem implementado as mais diversas motivações para se realizar uma viagem, propiciando o surgimento de novos segmentos, nos quais podem constituir ofertas específicas. Tais como observação de baleias, de pássaros, de turismo GLS (gays, lésbicas e simpatizantes), segmentos evangélicos entre outros que podem e devem ser trabalhados de forma individualizada, como nichos de mercado turísticos, ocasionando o aparecimento de agências de viagem e meios de transporte especializados que satisfaçam essa demanda, (DIAS, 2008).

E é através do conhecimento desses diferentes grupos que se torna possível a criação de novos produtos e serviços, desde que fique comprovada sua potencialidade e crescimento, podendose também detectar quais os produtos e serviços que estão em declínio, sendo esses substituídos por outros mais interessantes e desejados.

A divisão dos grupos homogêneos tende a ser feita adotando-se alguns critérios tais como geográfico, sociodemográfico, motivo da viagem, psicográfico (estilo de vida e personalidade), comportamento e outros (MINISTÉRIO DO TURISMO) ${ }^{4}$..

Então, por ser a segmentação de suma importância para a organização e gestão do mercado turístico, foi que o MTur - Ministério do Turismo ${ }^{5}$, segmentou o turismo no Brasil para fins estratégicos:

- Turismo Social é a forma de conduzir e praticar a atividade turística promovendo a igualdade de oportunidades, a equidade, a solidariedade e o exercício da cidadania na perspectiva da inclusão.

- Ecoturismo é um segmento da atividade turística que utiliza, de forma sustentável, o patrimônio natural e cultural, incentiva sua conservação e busca a formação de uma consciência ambientalista através da interpretação do ambiente, promovendo o bem estar das populações.

- Turismo Cultural compreende as atividades turísticas relacionadas à vivência do conjunto dos elementos significativos do patrimônio histórico e cultural e dos eventos culturais, valorizando e promovendo os bens materiais e imateriais da cultura.

- Turismo Cívico ocorre em função de deslocamentos motivados pelo conhecimento de monumentos, fatos, observação ou participação em eventos civicos, que representam o presente ou memória política e histórica de determinados locais.

Marcos_Conceituais.pdf . acesso em 06/05/2009

${ }^{4}$ Idem

${ }^{5}$ Idem 
- Turismo Religioso configura-se pelas atividades turísticas decorrentes da busca espiritual e da prática religiosa em espaços e eventos relacionados às religiões institucionalizas.

- Turismo Místico e Esotérico caracterizam-se pelas atividades turísticas decorrentes da busca da espiritualidade e do autoconhecimento em práticas, crenças e rituais considerados alternativos.

- Turismo Étnico constitui-se das atividades turísticas decorrentes da vivência de experiências autênticas em contatos diretos com os modos de vida e a identidade de grupos étnicos.

- Turismo de Estudo e Intercâmbio constitui-se de movimentação turística gerada por atividades e programas de aprendizagem e vivências para fins de qualificação, ampliação de conhecimento e de desenvolvimento pessoal e profissional.

- Turismo de Esportes compreende as atividades turísticas decorrentes da prática, envolvimento e observação de modalidades esportivas.

- Turismo de Pesca compreende as atividades turísticas decorrentes da prática da pesca amadora.

- Turismo Náutico caracteriza-se pela utilização de embarcações náuticas como finalidade da movimentação turística.

- Turismo de Aventura compreende os movimentos turísticos decorrentes da prática de atividades de aventura de caráter recreativo e não competitivo.

- Turismo de Sol e Praia constitui-se das atividades turísticas relacionadas à recreação, entretenimento ou descanso em praias em função da presença conjunta de água, sol e calor.

- Turismo de negócios e eventos compreende o conjunto de atividades turísticas decorrentes de interesse profissional, associativo, institucional, de caráter comercial, promocional, técnico, científico e social.

- Turismo rural é um conjunto de atividades turísticas desenvolvidas no meio rural, comprometido com a produção agropecuária, agregando valor a produtos e serviços, regatando e promovendo o patrimônio cultural e natural da comunidade.

- Turismo de saúde constitui-se das atividades turísticas decorrentes da utilização de meios e serviços para fins médicos, terapêuticos e estéticos.

É importante observar como a segmentação é importante nos dias atuais, pois por meio dela se pode descobrir novos mercados, nichos carentes de trabalho e especialização. E só é possível segmentar com êxito se houver observação detalhada de vários mercados, os quais possibilitarão a criação de novos negócios, serviços e produtos. Contudo, o olho no mercado deve ser constante, pois a informação e as necessidades estão latentes, oportunizando novos negócios a todo o momento, como dito anteriormente. 
Para enfatizar ainda mais a importância da segmentação do turismo que iremos detalhar em tópicos as vantagens de sua utilização ${ }^{6}$ :

- Ocorre uma identificação dos públicos-alvos mais rentáveis e aqueles segmentos nos quais à competição é mais fraca;

- Há uma definição mais precisa do mercado em função das necessidades dos consumidores que ainda não foram satisfeitas, podendo representar mais oportunidades de negócio;

- Facilita-se uma adaptação a possíveis mudanças de demanda;

- Os recursos destinados ao marketing são otimizados, havendo ainda melhor controle da sua aplicação em cada segmento;

- Melhora a comunicação promocional, direcionando-se para determinado público-alvo.

O Brasil, por ser um país de dimensões continentais, possibilita a utilização de diversos segmentos do turismo, dentre eles podemos destacar as principais segmentações do Brasil: Turismo de sol e praia, turismo cultural que se subdivide em patrimônio histórico, patrimônio arqueológico, gastronomia, religioso, de museus, patrimônio antropológico (constituído por celebrações folclóricas, festas populares), patrimônio rural com suas singularidades das antigas produções rurais, acontecimentos culturais pré-programados, como shows, festivais e festas em geral, turismo urbano, que engloba as atrações culturais da cidade, turismo voltado para natureza como ecoturismo, turismo rural, observação de animais, safáris, turismo de aventura ou esportivo, turismo de pesca esportiva e por fim turismo de negócios. (DIAS, 2008).

A rápida descrição dos segmentos do turismo no parágrafo anterior não pretende esgotá-los, mas somente detalhar aqueles principais. Valendo lembrar que, as possibilidades e a mutação desses seguimentos, são esperadas devido ao aparecimento de novos nichos, mercados e necessidades a quase todo momento. Contudo, mesmo fazendo uma boa segmentação do mercado, faz-se primordial a definição de estratégias turísticas muito bem estruturadas e fundamentadas para que o público alvo, ou o segmento a ser trabalhado, seja alcançado de forma eficaz.

${ }^{6}$ CF. Valls (2003); Lanquar (2001); Tabares (2000) apud DIAS (2008) 


\subsubsection{Gestão Estratégica de Destinos Turísticos no Mundo Globalizado}

Planejamento estratégico é um processo de desenvolvimento e manutenção da adequação entre os objetivos da empresa e suas competências e as mutáveis oportunidades de mercado. $O$ planejamento estratégico se baseia no desenvolvimento de uma missão institucional clara, de metas e objetivos viáveis, de uma estratégia perfeita e da implementação adequada. (KOTLER; HAYES; BLOOM, 2002, pg. 145)

O planejamento estratégico faz parte do cotidiano de qualquer empresa ou destino turístico, ou seja, os seus objetivos e metas têm que estar muito bem definidas e alinhadas com as ações empresariais ou institucionais e ainda em sintonia total com as mudanças advindas do mercado.

A gestão de negócios turísticos no mundo globalizado nos mostra a interligação de mercados nacionais e internacionais. Esses mercados são explorados e predominantemente dominados pelas empresas multinacionais que contam com grande aparato tecnológico, assim, muitos postos de trabalhos acabam desaparecendo, como é o caso das companhias aéreas que estão substituindo os funcionários pela internet e sistemas automatizados. Por outro lado, a maioria da massa não consegue acompanhar os novos empregos que estão surgindo, e nem ser absorvida pelo mercado de trabalho, principalmente naquelas destinações turísticas que são carentes de mão de obra qualificada. Porém, essas não são as maiores mudanças causadas pela globalização na gestão do turismo, o que pode aumentar ainda mais o desemprego, são:

"Mudanças de sede ou de um setor de multinacionais para outro país ou até
mesmo de estado; mudanças de ramo da empresa em busca de produtos
competitivos; aumento da competitividade e o livre mercado; abertura de
importações no país, com redução de impostos para multinacionais, isto gera
perda de poder aquisitivo e a impulsão do mercado turístico local; por outro
lado, as grandes corporações internacionais do turismo, também vem agindo
desta forma, e neste caso o Brasil tem sido privilegiado nesses últimos anos,
com a instalação, crescendo em nivel exponencial." (FONSECA, apud
BORBA, 2008, p. 2) Por um outro prisma, pode-se verificar também que a gestão de negócios turísticos no mundo globalizado através dessas multinacionais, propicia a maior interligação entre os países, mais visitas, viagens e trocas culturais. Pois, se houver um trabalho e um planejamento estratégico bem elaborado, com respeito e ética nessas destinações, acaba-se estimulando a valorização da cultura local e o aumento de sua auto estima. Nota-se, ainda, que não é suficiente ter uma mão de obra qualificada no hotel, atendimentos diferenciados, agências especializadas, infraestruturas modernas e de alto nível. Precisa-se disso tudo, porém a comunidade local deve 
manter suas tradições, se preparar para receber bem os visitantes e estes, os turistas, devem respeitar o local visitado, não poluir, não danificar o patrimônio entre outros, tudo isso para que o negócio se diferencie, perpetue e possa atrair novos turistas conscientes.

O mundo está cada vez mais parecido, principalmente nas grandes cidades, onde se encontra as mesmas lojas e redes de restaurante chamados de "fastfood". Por tudo isso que as pessoas estão cada vez mais sedentas pelo novo, diferente e o exótico, algo que atraia sua atenção, de forma a encantá-los. $\mathrm{E}$ isso tudo só será possível com o desenvolvimento do turismo embasado no código mundial de Ética, criado pela OMT - Organização Mundial do Turismo, que regulamenta o desenvolvimento do Turismo de forma a colaborar com o desenvolvimento local sustentável, no âmbito econômico, social e ambiental e não somente em sua exploração predatória, sem critérios ou planejamento. Como diz Boitex (apud BENI 2002, pg. 32) o "Turismo é um instrumento institucional de auto-educação, de tolerância mútua e de aprendizagem das diferenças entre povos e culturas e não somente para aumentar a ocupação dos hotéis ou simplesmente lotar cidades turísticas".

Outro detalhe importante abordado no livro estratégias para eventos de Janaina Britto e Nena Fontes (2002, p. 200) é que uma cidade que desperta para a sua vocação turística, precisa-se planejar e se organizar para receber o turista, porém esse tipo de turista de lazer já não é mais suficiente para atender e manter as destinações turísticas, em razão da sazonalidade. Com isso os destinos estão recebendo orientações da Embratur e consultores especializados, para oferecerem seus produtos turísticos o ano todo e uma das principais orientações é a elaboração de um calendário de eventos. Mas, antes de lançar um calendário de eventos ou fazer uma promoção, a cidade deve identificar a sua vocação turística maior, pois cada cidade tem sua própria cultura e singularidade, as quais devem ser respeitadas e pautadas na elaboração do calendário. Ressaltam, ainda, que quando uma cidade se lança na realização de eventos periódicos, esse processo acaba gerando um fomento no segmento turístico como todo, principalmente de turismo de eventos e negócios, ocasionando um fluxo maior de visitação nos atrativos originais.

Continuando nessa linha de pensamento, quando uma cidade começa a se despertar para o turismo é primordial analisar como a mesma deve ser promovida, e para Aníbal Teixeira (2002, p. 25-26) é preciso levar em conta alguns fatores preliminarmente, que são: 
- O que a área tem como base para sustentar a imagem que se pretende promover: Buscar referências econômicas, geográficas e culturais para que faça com mais facilidade a conexão entre o que se pretende promover e a realidade.

- A que público se destina a imagem: Buscar uma imagem que não conflita com o objetivo central pretendido, que esteja em sintonia com o segmento visado. Por exemplo: se o objetivo é atrair turista, o foco da imagem deve ser lazer, segurança, paz, etc.

- Instrumentos ou veículos: Quando se tem diferentes públicos alvos, o importante é evitar o conflito entre eles, buscando pontos comuns na concepção da imagem como qualidade de vida, beleza, tranqüilidade e segurança, que são pontos válidos para todos os públicos.

O mesmo autor diz que, para construir a imagem de uma cidade, perante o público alvo, imprescindível avaliar o seguinte (TEIXEIRA, 2002, p.27):

- Deve ser aceitável, isto é, não deve chocar o consenso geral;

- Deve ser simples e de fácil absorção, evitando generalizações;

- Deve ser motivadora e atraente com expressões como "amor", "paz" e outras;

- Deve ter foco, mesmo que genérico.

Já a estratégia para converter uma cidade em pólo turístico, segundo ele, deve ser seguir setes passos primordiais, que são:

- Diagnóstico do que existe (monumentos, recursos naturais, restaurantes, hotéis etc.)

- Nível de motivação da comunidade e de empresários locais;

- Plano turístico envolvendo ações públicas, estímulos à iniciativa privada e marketing;

- A fonte de recursos, para converter os pontos escolhidos em fontes de interesse para visitantes;

- Projetos privados de restaurantes, hotéis e pousadas;

- Programa de propaganda e marketing. 
Então, todos as abordagens citadas anteriormente, são muito importantes para o planejamento estratégico e na construção de uma imagem turística de um destino, porém, é fundamental conhecer bem o destino e levantar a existência de fontes motivadoras; saber o que o destino quer e onde quer chegar; levantar seus pontos fortes, fraquezas, metas e objetivos, e a assim se posicionar de forma competitiva, planejada e estratégica frente ao seu público alvo e satisfazer suas necessidades de forma diferenciada para que o destino se sustente e perdure.

O posicionamento competitivo, abordado no parágrafo anterior, nada mais é que a arte de desenvolver as diferenças significativas entre os serviços prestados pela empresa e os oferecidos pelos concorrentes que atuam no mesmo mercado. (KOTLER; HAYES; BLOOM, 2002, p.181)

Hoje, numa época vastamente competitiva, muitas empresas, não só do turismo, mas de todos os setores estão se perguntando: “Quais são as estratégias e as táticas de diferenciação que as empresas estão adotando para estabelecer, manter ou ampliar uma vantagem competitiva?". Essa pergunta foi feita a 422 importantes empresas nos Estados Unidos e Canadá. Veja na tabela a seguir, as estratégias por elas mais utilizadas

Tabela 01 - Estratégias e táticas de diferenciação:

\begin{tabular}{|l|l|}
\hline Abordagens para diferenciação & \multicolumn{1}{|c|}{$\begin{array}{c}\text { Percentual de } \\
\text { respostas } \\
\text { afirmativas }\end{array}$} \\
\hline Aperfeiçoamento ou modernização dos serviços atuais & $68 \%$ \\
\hline Reorganização dos processos ou linhas de serviços & $55 \%$ \\
\hline $\begin{array}{l}\text { Participação em empreendimentos conjuntos, alianças ou redes de } \\
\text { contatos, com o objetivo de ampliar o volume de serviços prestados. }\end{array}$ & $\mathbf{5 3 \%}$ \\
\hline Contratação de pessoal especializado & $52 \%$ \\
\hline Acréscimo de novas variáveis aos preços & $46 \%$ \\
\hline Reformulação dos serviços prestados atualmente & $43 \%$ \\
\hline $\begin{array}{l}\text { Utilização de novas técnicas e novos instrumentos para entregar } \\
\text { serviços (por exemplo, entrega de relatórios em CD-ROM, } \\
\text { abandonando os relatórios impressos) }\end{array}$ & $42 \%$ \\
\hline
\end{tabular}




\begin{tabular}{|l|l|}
\hline $\begin{array}{l}\text { Treinar profissionais que sigam as metodologias patenteadas da } \\
\text { empresa }\end{array}$ & $40 \%$ \\
\hline Desenvolvimento de um novo posicionamento & $40 \%$ \\
\hline
\end{tabular}

Fonte: (KOTLER; HAYES; BLOOM, 2002, p. 183)

É importante notar que a inovação foi parte das principais abordagens, se não todas, listadas no quadro anterior. Pois para reorganizar e modernizar uma empresa, descobrir alianças, contratar pessoal especializado, agregar valor aos preços, reformulação dos serviços prestados entre outras, nada mais é que pensar em fazer algo, porém de maneira diferente e eficiente. Como essas empresas são as maiores, estão entre as mais importantes do mundo e estão indo nessa direção, acredita-se então que são estratégias importantes a se rever e aplicar nos dias atuais.

\subsection{Turismo de Eventos e Negócios}

\subsubsection{Turismo de Eventos e suas características}

Ao verificarmos a historicidade do turismo de eventos e sua contextualização verificamos que a palavra, evento, vem do Inglês, "coming events". E o primeiro evento datado, foi a realização da Primeira Olimpíada, na cidade de Olímpia, em 776 a.c, na Grécia antiga, em honra a Zeus. A partir de então o evento esportivo passou a acontecer periodicamente, instaurando também a ordenação de outros eventos, como festas e encontros de todos os tipos em locais diversos, como anfiteatros, circos e arenas. Roma também se destacou nesta atividade, uma cidade com um apogeu econômico inigualável para a época, com 1 milhão de habitantes, ergueu uma suntuosidade para grandes espetáculos, o Coliseu, com capacidade para 50 mil espectadores.(SECRETARIA DE TURISMO DO PARANÁ, 2008) ${ }^{7}$

Para o Ministério do Turismo ${ }^{8}$, o Turismo de eventos e negócios "compreende o conjunto de atividades turísticas decorrentes dos encontros de interesse profissional, associativo, institucional, promocional, técnico, científico e social”, como já foi já citado na introdução.

\footnotetext{
${ }^{7}$ Disponível em: http://www.pr.gov.br/turismo/turismo_tipo_eventos.shtml?turistas, acesso dia 15/04/09

${ }^{8}$ MINISTÉRIO DO TURISMO, Segmentação do turismo disponível em: http://www.mda.gov.br/saf/arquivos/0708519758.pdf acesso em 09/04/09
} 
Entretanto observa-se que existem diversas óticas de análise e conceituação do turismo de negócios. Por exemplo, Moraes (1999, p. 31) explica o turismo de negócios como um segmento determinado pela motivação da viagem - negócios - que, por isso, tem características específicas. Ansarah (1999, p. 35-55) aborda que se trata de um segmento do turismo que ocorre em metrópoles ligadas à indústria e aos serviços, e também relaciona esta modalidade de turismo a eventos que impulsionam a realização de contatos profissionais ou a obtenção de conhecimentos que favoreçam negócios.

Nas destinações turísticas de eventos e negócios normalmente se verifica a instalação de grandes empresas organizadoras de eventos e convenções, com infraestrutura completa para receber eventos de pequeno, médio e grande porte, nacionais e internacionais. Esta infraestrutura seria, basicamente, composta por hotéis sofisticados, grandes centros de convenções, mão de obra qualificada e, além de tudo, deve ter localização estratégica, ou seja, fácil acesso, excelente rede de transporte terrestre e aéreo. E, ainda, para se consolidarem no mercado de turismo de eventos e negócios, as empresas organizadoras e fomentadoras desta modalidade, devem se apoiar em instituições sociais, privadas, públicas, associações das mais diversas, científicas e esportivas, assim como programas de incentivos, facilidades e outras atrações.

A instalação de um Convention and Visitors Bureau, fundação de caráter privado, sem fins lucrativos, se tornou muito importante para divulgação e captação de eventos, pois contam com uma estratégia de marketing e parcerias com outros conventions, que já detêm experiências na área. Já o consumidor, o turista de negócios e eventos, no caso específico deste segmento do turismo, é aquele participante, ouvinte ou palestrante em congressos, convenções, assembléias, simpósios, seminários, reuniões corporativas, work shops, conferência, lançamentos, feiras, festivais, shows, encontros culturais entre outras tipologias de evento. (Dias, 2008)

O Brasil já está entre os principais países receptores de eventos internacionais do mundo, realiza em média 300 mil eventos por ano, destes mais de 50\% estão concentrados na região sudeste, sendo que a região nordeste concentra a maior média de eventos por espaço, 209 eventos ao ano, e ainda gera uma mão de obra média variável de 16 vezes maior do que a fixa, segundo dados da Confederação Brasileira de Convetion \& Visitors Bureax ${ }^{9}$,

\footnotetext{
${ }^{9}$ Disponível em: http://www.fbcevb.com.br/eventos.asp acesso em 06/04/2009
} 
Com a divulgação do ranking da ICCA 2008, o Brasil ficou entre os dez países do mundo que mais sediam eventos internacionais, consolidando a atuação brasileira no segmento. Num estudo recente feito pelo Embratur, revela a descentralização dos locais onde são realizados os eventos internacionais. Em comparação com 2003, que foram apenas 22 cidades que realizaram eventos internacionais de acordo com os critérios da ICCA (encontros itinerantes, com periodicidade fixa e no mínimo de 50 participantes), saltou em 2008 para 42 diferentes cidades. São Paulo continua na liderança, sendo a cidade das Américas que mais recebeu eventos internacionais. Entretanto, percebe-se a participação de outras cidades como Rio de Janeiro, Foz do Iguaçu, Porto Alegre, Brasília, Belo Horizonte, Florianópolis e Recife, figurando, todas essas, no ranking internacional da ICCA 2008. O setor de eventos está muito otimista com a posição do Brasil no ranking e agora com a criação do banco brasileiro de eventos até 2010, o setor poderá se fortalecer ainda mais, pois contará com o cadastro do banco de eventos, se organizará melhor e elaborará políticas públicas mais consistentes. (PERES, 2009)

Segundo Janaina Britto e Nena Fontes (2002), o Brasil já está consciente de que o turismo de eventos é importante para o desenvolvimento do país, sendo assim, observa-se um maior investimento em melhorias nos aeroportos, rodoviárias, transportes, centros de convenções, bem como o oferecimento de subsídios para a construção de hotéis. Devido a essas melhorias feitas pela rede pública, a iniciativa privada acaba se mobilizando para se organizar e se estruturar, para oferecer serviços complementares com padrões semelhantes aos encontrados nos principais destinos turísticos. Com a vinda de mais eventos, as agências de viagens se especializam na organização de eventos, organizando congressos, feiras, lazeres noturnos, aumento no número de shoppings, e elas garantem que nossos equipamentos já se equiparam com os países do primeiro mundo.

Com essa crescente oferta de eventos mundiais é mister entendermos um pouco como funciona a captação de eventos nos núcleos receptores. Segue abaixo roteiro simplificado dos 3 passos básicos que envolvem a captação de eventos, segundo Janaina Britto e Nena Fontes (2002, p. 40-41):

- Análise das condições do núcleo para sediar eventos: Existência de espaço para realização de eventos, capacidade hoteleira, transportadores turísticos, atrações turísticas (belezas naturais, clima, equipamentos de lazer); traços culturais e sociais; as condições de infra-estrutura do núcleo como aeroportos; terminais rodoviários; segurança, rede de 
comunicações; equipamentos técnicos disponíveis como salões, salas, auditórios e serviços como de coquetel, coffee-break, banquete e outros que permitam atividades simultâneas de evento; aspectos políticos, econômicos, culturais, industriais, que possam, direta ou indiretamente, ampliar o interesse dos participantes.

- Avaliação dos tipos de eventos que podem ser realizados no núcleo: levantamento dos eventos a serem realizados e ainda sem definição do local de instalação; levantamento das características de cada eventos quanto à temática, período de duração, perfil do público e quantidade estimada, necessidades técnicas, possibilidades de patrocínio, apoio e divulgação; análise das condições reais dos núcleos para atender às necessidades do evento que o núcleo tem interesse em sediar e análise das repercussões do evento no mercado turístico do núcleo.

- Definição da estratégia de captação de eventos para o núcleo: Diferenciação por meio dos recursos humanos: profissionalismo, cortesia, competência, credibilidade; diferenciação por meio de imagem: Estratégia de comunicação, que deverá ser focado no público alvo, enfatizando os aspectos facilitadores para a realização dos eventos; diferenciação por meio de atrativos turísticos: para despertar no participante o interesse em conhecer; diferenciação por meio de equipamentos e tecnologia disponível indispensável na estratégia de comunicação e pode ser decisivo no sucesso de uma captação.

E para identificar melhor os tipos de eventos que podem ser realizados, vamos demonstrar a seguir a classificação dos eventos e suas tipologias de acordo com as autoras Janaina Britto e Nenna Fontes (2002, p. 59-62):

- Categoria: Institucional ou Promocional e/ou Mercadológico;

- Área de interesse: Artística, científica, cultural, educativo, Cívica, política, Governamental, Empresarial, Lazer, social, desportiva, religiosa, beneficente, turística;

- Localização: Bairro, distritais, municipais, regionais, estaduais, nacionais e internacionais;

- Características estruturais: Evento de pequeno porte: 200 pessoas, evento médio porte: entre 200 a 500 pessoas e grande: acima de 500 pessoas ;

- Classificação por tipologia: 
Quadro 01 - Classificação dos eventos por tipologia:

\begin{tabular}{|c|c|}
\hline Programas de visitas & $\begin{array}{l}\text { Famtour } \\
\text { Openday }\end{array}$ \\
\hline Exposições & $\begin{array}{l}\text { Feiras } \\
\text { Exposições } \\
\text { Road-shows } \\
\text { Show case } \\
\text { Mostras } \\
\text { Salões } \\
\text { Vernissages }\end{array}$ \\
\hline Encontros técnicos e Científicos & $\begin{array}{l}\text { Congressos } \\
\text { Conferências } \\
\text { Videoconferências } \\
\text { Ciclos de Palestras } \\
\text { Simpósios } \\
\text { Mesas-redondas } \\
\text { Painéis } \\
\text { Fóruns } \\
\text { Convenções } \\
\text { Seminários } \\
\text { Debates } \\
\text { Conclaves } \\
\text { Brainstormings } \\
\text { Semanas } \\
\text { Jornadas } \\
\text { Concentrações } \\
\text { Entrevistas coletivas } \\
\text { Workshops } \\
\text { Oficinas } \\
\text { Assembléias } \\
\text { Estudos de caso } \\
\text { Comícios } \\
\text { Passeatas } \\
\text { Carreatas }\end{array}$ \\
\hline Encontros de Convivência & $\begin{array}{l}\text { Saraus } \\
\text { Coquetéis } \\
\text { Happy-hours } \\
\text { Chás da tarde } \\
\text { Chás de bebê } \\
\text { Chás de cozinha } \\
\text { Chás beneficentes } \\
\text { Chás bar } \\
\text { Almoços } \\
\text { Jantares } \\
\text { Banquetes } \\
\text { Cafés da manhã } \\
\text { Brunches } \\
\text { Coffee breaks }\end{array}$ \\
\hline
\end{tabular}




\begin{tabular}{|c|c|}
\hline & $\begin{array}{l}\text { Guest coffees } \\
\text { Encontros culturais } \\
\text { Shows } \\
\text { Festivais }\end{array}$ \\
\hline Cerimônias & $\begin{array}{l}\text { Cerimônias de cunho religioso } \\
\text { Cerimônias fúnebres } \\
\text { Casamentos } \\
\text { Bodas } \\
\text { Cerimônias de Posse } \\
\text { Cerimônias acadêmicas (Formatura, outorga de } \\
\text { títulos, aula magna) }\end{array}$ \\
\hline Eventos competitivos & $\begin{array}{l}\text { Concursos } \\
\text { Gincanas } \\
\text { Torneos } \\
\text { Campeonatos } \\
\text { Olimípiadas } \\
\end{array}$ \\
\hline Inaugurações & $\begin{array}{l}\text { Espaços físicos } \\
\text { Monumentos } \\
\text { (históricos e homenageativos) }\end{array}$ \\
\hline Lançamentos & $\begin{array}{l}\text { Pedra fundamental } \\
\text { De livros } \\
\text { De empreendimentos imobiliários } \\
\text { De maquetes } \\
\text { De produtos } \\
\text { De serviços } \\
\end{array}$ \\
\hline Excursões & $\begin{array}{l}\text { Técnicas } \\
\text { De incentivo } \\
\text { Educacionais }\end{array}$ \\
\hline Desfiles & $\begin{array}{l}\text { Cívicos } \\
\text { De moda }\end{array}$ \\
\hline Leilões & Variados \\
\hline Dias específicos & Variados \\
\hline Outros & Variados \\
\hline
\end{tabular}

Fonte: (BRITTO; FONTES, 2002, p. 59-62) 


\subsubsection{Características básicas do Turista de Eventos e Negócios}

Analisando os serviços utilizados pelo turista de eventos e negócios, vários autores, entre eles, Lickorish e Jenkins (1997, p. 74), alegam que eles demandam os mesmos serviços utilizados pelo turista de lazer, porém com duas distinções, geralmente o turista de eventos e negócios, preocupa-se menos com o preço, devido às despesas serem arcadas pela empresa e preocuparse mais com a localização e conforto do estabelecimento hoteleiro. São estes os turistas motivados a realizarem negócios, desses, apenas uma pequena parcela é internacional, maioria deles vem de localidades próximas aos eventos, maioria é composta de homem de negócios, público adulto, grande parcela casados, alto poder aquisitivo, economicamente ativos. Já para Swarbrooke (2000, p. 85), o turista de negócios é um turista que viaja mais que o turista convencional, que acaba os tornando mais exigentes, pois tendem a retornar mais de uma fez àquele destino. Porém, segundo Débora Cordeiro ${ }^{10}$, no seu artigo: Características do turista de negócios de São Paulo, relata a existência de outra parcela significativa de turista de eventos e negócios, que muitas das vezes não é considerado no planejamento deste segmento, são os turistas da região, normalmente profissionais liberais, autônomos, menor poder aquisitivo, sem vínculo empregatício, os quais demandam por outros serviços, que não os luxuosos, pois são eles que arcam com todas as despesas da viagem. Ela diz ainda que estes turistas de eventos e negócios, agora como todo, é um público que viaja mais, sem muito espaço para o lazer, porém foi detectado que muitos têm interesse pela cultura local, culinária e atrações, isso claro, dependendo da atratividade do destino.

Em uma outra pesquisa realizada em 2006 pela Promotur, Univelle (Universidade da Região de Joinvelle) e JOCVB (Joinville Costa do Encanto Convention \& Visitors Bureau) ${ }^{11}$, para traçar o perfil do turista de eventos e negócios, chegou-se a seguinte conclusão, que cada evento, por ter sua particularidade, atrai públicos específicos, não existindo assim uma característica única para o turista de eventos e negócios. Contudo Débora Cordeiro ${ }^{12}$, acredita na existência de 2 tipos clássicos de turistas de negócios e eventos, numa visão mais econômica: primeiro é aquele que não se preocupa com o preço dos serviços e produtos e sim

\footnotetext{
${ }^{10}$ BRAGA, Débora Cordeiro. Turistas de negócios na cidade de São Paulo: Teoria versus a realidade, expressão ", disponível em: http://www.unisantos.com.br/pos/revistapatrimonio/artigos.php?cod=109\&bibliografia=1\&, acesso em $09 / 12 / 08$

${ }^{11}$ Disponível em: http://www.pr.gov.br/turismo/turismo tipo eventos.shtml?turistas acesso em 15/04/09

${ }^{12}$ BRAGA, Débora Cordeiro. Turistas de negócios na cidade de São Paulo: Teoria versus a realidade, expressão “ disponível em:”,http://www.unisantos.com.br/pos/revistapatrimonio/artigos.php?cod=109\&bibliografia=1\&, acesso em 09/12/08
} 
com o luxo, conforto, comodidade e localização, pois os recursos são oriundos da empresa em que trabalha e o segundo é aquele com menor poder aquisitivo, que procura alternativas mais baratas, sem muito luxo em virtudes de restrição financeira ou da empresa a qual está vinculado.

Analisando o comportamento do consumidor do turismo de eventos e negócios. Para Robert Pindyck e Daniel Rubinfield (2006), o comportamento do consumidor em geral é examinado em três etapas distintas: preferências do consumidor, restrições orçamentárias e escolhas do consumidor. Nestas etapas pode-se analisar porque um produto é preterido ao outro, que produto melhor adequa a renda daquela população e de acordo com a escolha feita, pode-se entender melhor a demanda por aquele serviço.

Deduz-se então a existência de 2 tipos de turista de eventos e negócios, o primeiro que escolhe o seu produto turístico, assim dizendo, baseado mais no conforto, comodidade e luxo do que no preço em si. Imagina-se então que o aumento do preço da hotelaria, restaurante e do transporte aéreo não interferirá na sua viagem, pois quem arca com as despesas é a companhia na qual ele trabalha.

Já o segundo tipo de turista de eventos e negócios, muitas vezes negligenciado pelo empresariado do setor, como diz Braga ${ }^{13}$, no seu artigo já citado anteriormente. Estes turistas são aqueles profissionais liberais, autônomos, estudantes e funcionários de empresas menos abastadas, este sim é mais suscetível ao aumento de preço. Eles tentarão maximizar ao máximo seus gastos de acordo com sua renda, buscando meios de hospedagem e transporte compatíveis com seu padrão de vida. E caso este preço aumente consideralmente ele pode deixar de consumir este produto ou substituí-lo por um perfeito. 


\subsubsection{A importância do Turismo de Eventos e Negócios e seus impactos no destino}

Uma das principais importâncias do Turismo de Eventos e Negócios é que ele independe da sazonalidade, pois geralmente os organizadores e expositores procuram a baixa temporada para a realização dos seus grandes eventos, ou seja, o Turismo de Eventos e Negócios propicia o aumenta da taxa média dos hotéis e em conseqüência movimenta todo o trade, pois o mesmo depende de transporte, alimentação, agenciamento de viagens entre outros e gera empregos diretos e indiretos, movimentando e incrementando a receita global do destino, pois esse tipo de turista gasta em média 3 vezes mais que o turista convencional. (BAHL, 2003)

Outro fator importante é que com o investimento em Turismo de negócios e eventos os órgãos públicos e iniciativa privada têm que investir em infraestrutura e preservação do patrimônio, então com a vinda desse segmento do turismo, toda a população no primeiro momento é beneficiada, pois há melhoria das estradas, transporte, hotelaria, restaurante, atendimento, saúde, lazer etc.

Interessante destacar também que o Turismo de Eventos e Negócios depende de uma mão de obra qualificada e uma maior consciência do trade na prestação de serviço, sendo assim, o investimento em treinamento deve ser feito, pois um evento mal coordenado, com péssimo atendimento, preços exorbitantes, pode gerar impactos negativos para o destino, como evasão de turistas, marketing negativo boca a boca, o não retorno do turista com os familiares.

Segue abaixo alguns dados estatísticos importantes do setor de turismo de negócios e eventos e sua abrangência, disponíveis no site da ABEOC - Associação Brasileira dos Organizadores de Eventos ${ }^{14}$ :

- O segmento de turismo de eventos movimenta cerca de US\$ 4 trilhões por ano no mundo;

- No Brasil o setor envolve aproximadamente 80 milhões de participantes;

- O setor gera por volta de 2, 9 milhões de empregos diretos e indiretos no Brasil;

- Representa o impacto em 54 setores da economia;

\footnotetext{
${ }^{14}$ Disponível em: http://www.abeoc.org.br/200801221736.php acesso em 28 de junho de 2009
} 
- Estima-se um crescimento de 7\% nos últimos anos no Brasil;

- Por ano, acontece cerca de 327 mil eventos e 160 grandes feiras no Brasil;

- O Brasil entrou na lista do Top 10 do mundo, quando alcançou a $7^{\mathrm{a}}$ colocação no ranking da ICCA. Em cinco anos, subiu 14 posições, uma vez que ocupava o $21^{\circ}$ lugar em 2002;

- O Brasil é o primeiro país latino americano a ocupar posição entre os 10 MAIS no ranking da ICCA;

- São Paulo, é a cidade Brasileira, considerada a capital latino americana dos eventos;

- No ranking da ICCA é a cidade que mais contabiliza eventos internacionais nas Américas, tendo superado ícones como Nova York, Miami e Toronto.

- São Paulo recebe 90 mil eventos por ano, ou seja, 1 evento a cada 6 minutos;

- Das grandes feiras realizadas no país anualmente, 75\% acontecem em São Paulo. Sem falar nos muitos eventos de grande porte nas áreas cultural e esportiva, como o São Paulo Fashion Week, a Virada Cultural e o GP Brasil de Fórmula 1.

Segundo Beni (2002), atualmente não existem dados confiáveis sobre a participação do turismo de eventos e negócios na economia do país, mas estima-se que a participação é considerável, por volta de 3,1\% do Pib Nacional. Levando em conta que, para calcular a renda da indústria de eventos, deve-se calcular além dos gastos feitos pelos turistas de eventos e negócios, os investimentos feitos pelos coordenadores de eventos como locação de espaços, equipamentos áudio-visual, mão de obra terceirizada entre outros, que compõem o orçamento total do segmento. 


\title{
2.3 Panorama Turístico de Brasília
}

\subsubsection{História de Brasília}

\begin{abstract}
"Deste planalto central, desta solidão que em breve se transformará em cérebro das altas decisões nacionais, lanço os olhos sobre o amanhã do meu país e antevejo esta alvorada com fé inquebrantável e uma confiança sem limites no seu grande destino.” Juscelino Kubitschek ${ }^{15}$
\end{abstract}

Desde a época da colonização já se cogitava a interiorização da capital Brasileira com o intuito de trazer o desenvolvimento para o interior do país e proteger a capital. O primeiro a cogitar essa transferência foi o Marquês de Pombal em 1716, mais tarde José Bonifácio de Andrade e Silva traz a tona novamente o assunto da interiorização da capital e sugere o nome Brasília.

Mas somente em 1883, que o Padre Dom Bosco, que estava em Turim, teve um sonho que lhe mostrava o surgimento de uma poderosa cidade entre os paralelos $15^{\circ}$ e $20^{\circ}$ e foi nesse exato paralelo que foi construída a capital Brasileira.

Após mil dias de trabalho ardo, precisamente em 21 de abril de 1960, Juscelino Kubitschek inaugura a nova Capital, construída em formato de um avião. ${ }^{16}$

É uma cidade planejada, projetada pelos arquitetos Lúcio Costa e Oscar Niemeyer, foi projetada inicialmente para 500 mil pessoas e atualmente conta com mais de 2,5 milhões, uma cidade cosmopolita, na qual existem 90 embaixadas e representações diplomáticas, brasileiros de todas as partes, localização privilegiada, no centro geográfico do Brasil e da América do Sul, clima agradável, com temperaturas que variam entre $18^{\circ} \mathrm{C}$ a $22^{\circ} \mathrm{C}$, porém a umidade do ar costumar ser baixa. Possui uma área verde considerável, 26.813 hectares, o que proporciona uma qualidade de vida maior para a população.

Brasília é uma capital jovem, formada por múltiplas culturas brasileiras, e que até pouco tempo atrás, eram, em sua maioria, oriundas de Goiás, Minas Gerais, Rio Grande do Sul e Bahia. Hoje, passados 49 anos de sua fundação, metade de sua população é composta por pessoas com menos de 49 anos e já nascidas no DF. Das 29 regiões administradas pelo DF já se percebe a formação de um sotaque próprio, ritmo de vida diferenciado, local onde as pessoas tendem a estudar mais, talvez pela possibilidade de seguir a vida pública, adoram

${ }^{15}$ Disponível em: http://www.gdf.df.gov.br/045/04501018.asp acesso em 10 de maio de 2009

${ }^{16}$ Idem 
internet e celular (média de 1,3 por habitante) e apresenta visão de mundo e são mais politizados que a média brasileira. É uma cidade onde o verde predomina, principalmente entre as quadras e nos parques da cidade. E um deles, o Parque da cidade Sarah Kubitscheck, localizado bem no centro da cidade, na asa sul, que conta com 400 hectares, possui três diferentes circuitos de caminha, cooper, passeio e ciclovia (4, 6 e 10km), sendo, por isso, classificado como o maior parque urbano da América latina. (RIELLA, 2009) ${ }^{17}$

Então, Brasília é uma cidade que pelos seus predicados e historicidade já justifica um trabalho neste porte, pois é a capital do país, centro das decisões, possui diversidades culturais expressivas, é jovem, tombada pela Unesco como Patrimônio da Humanidade desde 1987. É a primeira cidade moderna do mundo a receber este título, e a inclusão se deve a originalidade do plano urbanístico que foi calcado em quatro escalas, conforme a seguir ${ }^{18}$ :

- Escala Monumental: Representada pelo Eixo Monumental, onde estão dispostos os símbolos do poder do país.

- Escala Gregária: Corresponde a todos os setores de convergência da população: (Comerciais, bancário e hospitalar) e tem como marco a plataforma da Rodoviária do Plano Piloto, símbolo da união com as outras cidades do distrito.

- Escala Residencial: Representada pelas superquadras e seus conjuntos de edifícios sobre pilotis, para garantir a livre circulação de pessoas pelo chão.

- Escala Bucólica permeia-se com as demais, que são os gramados, praças, jardins, áreas de lazer, Parques da cidade e a orla do Paranoá.

E ainda é uma cidade que se destaca em diversos setores, como música, esporte, eventos, shows, culinária e cultura. Há mais de 40 anos realiza o Festival de Brasília do Cinema Brasileiro, a feira do livro, bienal da Poesia e outros como Expotchê, Festa de aniversário da Cidade de Brasília, que se transformou em um grande show, Festa dos Estados, Festa do Morango de Brazlândia entre outras.

\footnotetext{
${ }^{17}$ RIELLA, Renato. Brasília já é feita por Brasilienses. Revista Veja - Informe publicitário, Brasília, DF, Ed. 2009

18 Disponível em: http://www.brasiliaconvention.com.br/ acesso em 15 de maio de 2009
} 


\subsubsection{Principais atrativos do Distrito Federal e entorno}

Brasília já possui diversos atrativos, que vão desde os culturais como teatros, monumentos a diversos shows, festas e eventos como foi comentado no capítulo anterior. Conta ainda com diversos museus, festas temáticas a várias opções de bares, restaurantes, casas noturnas e centros de compras, com várias opções de shoppings também, e pode-se observar a intensificação desses atrativos na capital, com uma oferta cada vez maior desses serviços. Além das opções citadas anteriormente, não se pode deixar de destacar os parques da cidade, oferecendo uma área verde belíssima, que é um convite a prática de esportes.

Brasiliatur, autarquia criada para gerir e promover o turismo na capital, elaborou e dividiu as atrações turísticas da cidade em três diferentes segmentos do turismo, que são: Turismo Cívico/ Arquitetônico, Turismo Ecológico e Rural, Turismo Místico, classificando algumas atrações que não se pode deixar de ver e comentar, conforme demonstrado no seu site oficial do órgão: ${ }^{19}$.

O Turismo Cívico arquitetônico foi subdivido nas seguintes atrações:

- Praça dos três poderes

- Panteão da Pátria

- Espaço Lúcio Costa

- Espaço Oscar Niemeyer

- Congresso Nacional

- Supremo Tribunal Federal

- Palácio do Planalto

- Palácio Itamaraty

- Ministério da Justiça

- Esplanada dos Ministérios

${ }^{19}$ Disponível em: http://www.setur.df.gov.br/ acesso em 15 de maio de 2009 
- Catedral Metropolitana Nossa Senhora Aparecida

- Teatro Nacional Cláudio Santoro

- Centro Cultural da República

- Estação Rodoviária de Brasília

- Torre de Televisão

- Centro Esportivo Ayrton Senna

- Centro de Convenções Ulisses Guimarães

- Palácio do Buriti

- Memorial dos Povos Indígenas

- Memorial JK

- Praça do Cruzeiro

- Estação Ferroviária

- Quartel General do Exército

- Superquadras 107,108 e 308 sul

- Banco Central

- Caixa Econômica Federal

- Centro Cultural Banco do Brasil

- Superior Tribunal da Justiça

- Palácio da Alvorada

- Catetinho

- $\quad$ Ponte JK 
- Museu Vivo da Memória

O Turismo Ecológico e rural foi subdivido em:

- Parque da Cidade Sarah Kubitscheck

- Parque Nacional de Brasília (Água Mineral)

- Parque Olhos d'água

- Parque Águas Claras

- Jardim Botânico

- Estação Ecológica de Águas Emendadas

- Jardim Zoológico

- Chapada Imperial

- Parque Municipal Itiquira (Formosa GO)

- Lindas Serras dos Topázios (Cristalina GO)

- Chapada dos Veadeiros (Cidade de Alto Paraíso e São Jorge/GO)

- Cavalcante (Chapada dos Veadeiros/GO)

Lagos e lagoas:

- Lagoa e Barragem do Paranoá

- Lago Bonita (Planaltina/DF)

- Lagoa Formosa (Planaltina/DF)

- Lagoa Feia (Formosa/GO)

- Cachoeiras: Poço Azul (Brazlândia/DF), Mumunhas (Brazlândia/DF), Cachoeira da Saia Velha (DF), Piripipau (Planaltina DF), Salto do Corumbá (Corumbá de Goiás/GO), Cachoeira do Arrojado (Cristalina/GO), Salto do Tororó (DF), Buraco das Araras e Buraco das Andorinhas (Formosa/GO)

- Gruta do Tamboril (Unaí/MG)

- Gruta do Rio do Sal (DF)

- Gruta São Domingos (São Domingos/GO - Parque Estadual Terra Ronca) 
- Cidades históricas: Planaltina (DF), Pirenópolis (GO), Cidade de Goiás (GO), Corumbá de Goiás (GO), Cristalina (GO), Luziânia (GO), Formosa (GO), Caldas Novas (GO), Rio Quente (GO)

Turismo místico:

"...e entre os paralelos $15^{\circ}$ e $20^{\circ}$ Sul, havia em um leito muito largo e extenso que partia de um ponto onde se formava um lago. Quando escavarem as minas escondidas no meio desses montes, aparecerá aqui a grande civilização, a Terra Prometida de onde emana o leite e o mel..." (Profecia de São João Bosco, 1883)

- Catedral Metropolitana Nossa Senhora Aparecida

- Santuário Dom Bosco

- Igreja Nossa Senhora de Fátima

- Mesquita do Centro Islâmico do Brasil

- Templo Budista da Terra Pura

- Seichô-no-iê

- Catedral Santa Maria dos Milagres, Rainha da Paz

- Oratório do Soldado

- Comunhão Espírita

- Ermida Dom Bosco

- Igreja Messiânica Mundial

- Templo da Ordem Rosa Cruz

- Igreja Adventista do Sétimo Dia

- Templo da Boa Vontade

- Cidade Eclética (Santo Antônio do Descoberto/GO)

- Cidade da Paz

- Vale do Amanhecer

- Planaltina - Encenação da Via Sacra no Morro da Capelinha

- Pirenópolis - Festa do Divino

- Cidade de Goiás - Procissão do Fogaréu na quarta-feira da semana santa (Igreja Boa Morte) 
- Festa da Circuncisão

- Folia de Alvorada

Formando uma parceria com intuito de divulgar o potencial turístico brasiliense, Brasiliatur, Sebrae e diversos consultores concluíram que Brasília teria uma forte vocação turística cultural, mesmo sendo uma cidade jovem e centro administrativo do país, mas que impressiona pela história, cultura e, principalmente, pelas belezas e unicidade dos traços arquitetônicos de Oscar Niemeyer. Apostando nisso, lançaram cinco roteiros turísticos temáticos para diferentes públicos, que são: o arquitetônico, o cívico, o jurídico, o rural e o Brasília em Athos, para atrair turistas em busca de conhecimento, principalmente estudantes brasileiros e estrangeiros ${ }^{20}$.

$\boldsymbol{O}$ primeiro roteiro é o arquitetônico, para atender estudantes de arquitetura brasileiros e estrangeiros com interesse nas modernas técnicas dos projetos urbanísticos, arquitetônicos e paisagísticos da capital. Terá um tour por lugares da cidade que os fariam entender a dinâmica de sua construção.

No roteiro cívico o objetivo é o resgate dos valores patrióticos dos Brasileiros, mostrando principalmente às crianças a importância de se alimentar o conhecimento cívico. $\mathrm{O}$ tour será pela Praça dos Três Poderes, a destacar o Palácio do Planalto, inaugurado em 1960, marcado como símbolo da transferência do poder público para Brasília.

Já o roteiro jurídico tem como foco, não só os estudantes de direito de todo país, mas advogados, juízes e todos os militantes da seara jurídica que terão a oportunidade de vivenciar a origem, composição, funcionamento, competência e realidade dos Tribunais Superiores sediados nesta Capital Federal, com destaque para o Supremo Tribunal Federal (STF), órgão de Cúpula do Poder Judiciário, ao qual compete precipuamente a guarda da Constituição da República Federativa do Brasil, contando com 11 ministros, todos brasileiros natos, com mais de 35 anos e menos de 65, de notável saber jurídico e reputação ilibada, nomeados pelo Presidente da República, após aprovação pela maioria absoluta do Senado Federal.

Aos amantes da natureza será ofertado o roteiro rural, com belas paisagens, para descanso e diversão, além da agradável gastronomia regional. O intuito da criação desse roteiro é principalmente divulgar para os Brasilienses, residentes e visitantes que, bem mais próximo do que se pensam, existe uma grande diversidade de propriedades rurais, com trilhas

\footnotetext{
${ }^{20}$ Disponível em: http://www.skyscrapercity.com/showthread.php?t=511341 acesso em 06 de junho de 2009
} 
bucólicas e esportes radicais, que já contam com infraestrutura para receber turistas ecologicamente corretos.

E, com o intuito de homenagear o pintor, escritor, arquiteto, desenhista e mosaicista Athos Bulcão é que foi criado o quinto roteiro turístico de Brasília, chamado Brasília em Athos. Suas obras estão presentes em mais de quarenta atrações turísticas de Brasília. Os exemplos mais conhecidos são o relevo do Teatro Nacional, a Igrejinha da 307/308 Sul, o Parque da Cidade e o Hospital Sarah Kubitscheck.

Outro projeto que promete virar atração turística na capital é a Orla do Lago Paranoá. Além da reforma da Concha Acústica, que terá uma enorme marina pública, contará com quiosques, restaurantes e bares, tudo para aproximar os turistas e cidadãos da Orla do Lago. Estão previstos, ainda, estudos para ocupação de outras áreas beira-lago. ${ }^{21}$

\subsubsection{Turismo de Eventos e Negócios em Brasília}

Com a inauguração do Centro de Convenções Ulisses Guimarães em 2005, antigo Centro de Convenções de Brasília, a capital do país se integra às cidades que recebem eventos de grande porte. Agora o CCUG - Centro de Convenções Ulisses Guimarães aumentou sua capacidade e pode receber até 9.000 pessoas. Outro ganho para a cidade foi o Hotel Resort Brasília Alvorada Hotel e Centro de Eventos Brasil XXI para reforçar ainda mais a vocação da capital para o Turismo de Eventos.

Na pesquisa realizada recentemente sobre os Indicadores Econômicos para o Planejamento do Turismo no Distrito federal foi levantado nos setores hoteleiros o principal motivo da viagem a Brasília, chegando-se aos seguintes dados:

Tabela 02 - Motivos da viagem para o Distrito federal:

\begin{tabular}{|l|l|l|l|l|}
\hline MOTIVO DA VIAGEM & \multicolumn{4}{|c|}{ \% HÓSPEDES } \\
\hline & JU/07 & JAN/08 & FEV/08 & $\begin{array}{l}\text { MAR/ } \\
\mathbf{0 8}\end{array}$ \\
\hline LAZER & 6,20 & 10,26 & 6,41 & 4,89 \\
\hline NEGÓCIOS & $\mathbf{4 3 , 6 6}$ & $\mathbf{4 1 , 0 4}$ & $\mathbf{4 7 , 5 6}$ & $\mathbf{4 8 , 2 6}$ \\
\hline
\end{tabular}

${ }^{21}$ Idem 


\begin{tabular}{|l|l|l|l|l|}
\hline CONVENÇÃO & 13,40 & 13,61 & 10,10 & 16,00 \\
\hline OUTRO & 36,75 & 35,09 & 36,78 & 29,85 \\
\hline
\end{tabular}

Fonte: Pesquisa Indicadores Econômicos para o planejamento do turismo no Distrito Federal disponível em: www.cet.unb.br acesso em 05 de maio de 2009

\section{Tabela 3 - Principal motivo da viagem ao DF}

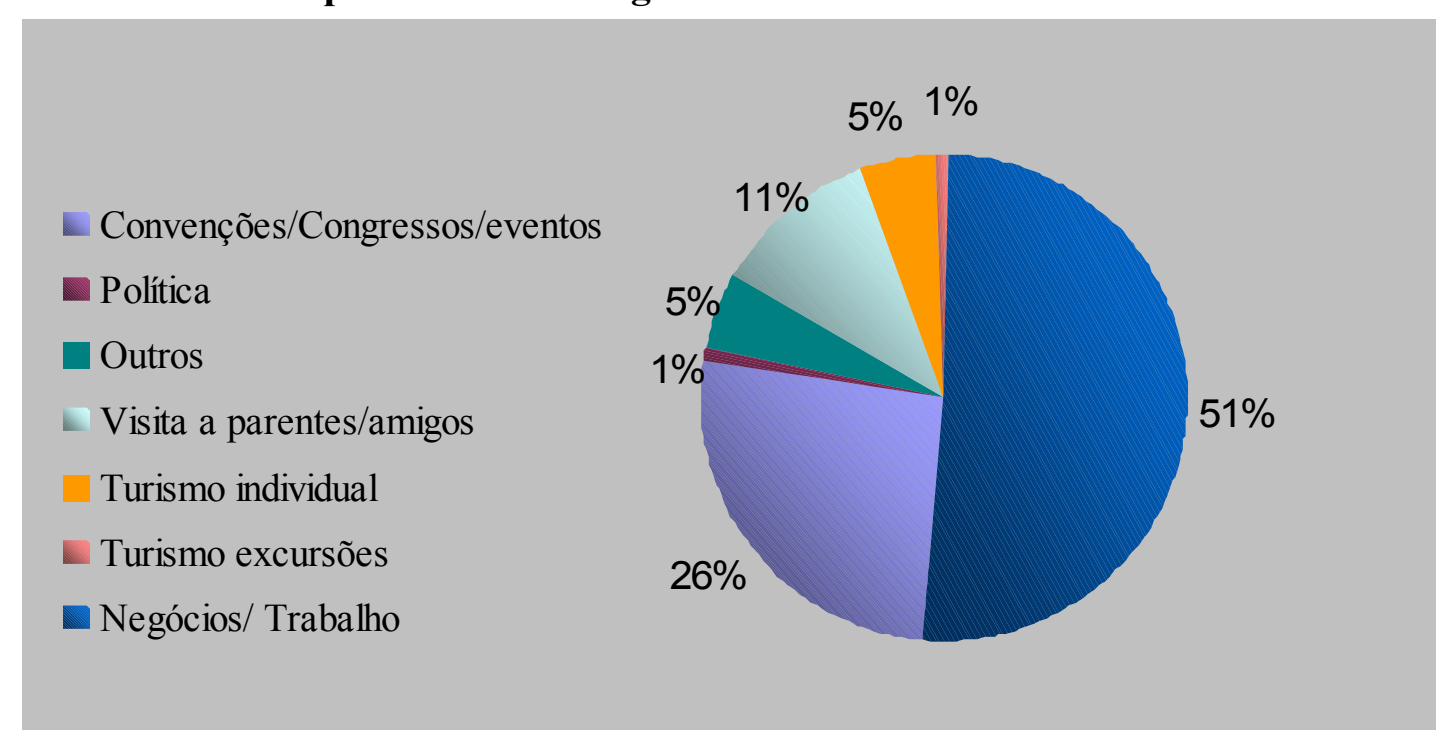

Fonte: Brasília Convention \&Visitors Bureau. Perfil do Turismo e o setor de eventos no Distrito Federal. São Paulo, 1996

A pesquisa realizada pelo CET - Centro de Excelência e Turismo em parceria com a Brasiliatur e a pesquisa do Brasília Convention mais uma vez comprova que até o momento, o turismo no Distrito Federal é particularmente de negócios e a maioria dos visitantes vem principalmente de São Paulo, Rio de Janeiro, sendo ínfima a recepção de turistas estrangeiros. Pode-se notar que mesmo a diferença de aproximadamente 10 anos em relação uma pesquisa com a outra, o panorama não mudou muito, continuando o turista de negócio a maioria do visitante a Brasília.

No site da SDET- Secretaria de Desenvolvimento Econômico e Turismo ${ }^{22}$, divulga 10 razões para que eventos sejam realizados na capital da república, conforme segue abaixo:

\section{1) Cidade Cosmopolita}

\footnotetext{
${ }^{22}$ Disponível em: http://www.setur.df.gov.br/ acesso em: 15/04/09
} 
Brasília é uma cidade de braços abertos para o mundo. A cidade está acostumada a receber grandes delegações; só na posse presidencial de 2003, 187 países estiveram aqui representados:

- Em Brasília existem 90 embaixadas e representações diplomáticas;

- Desde sua fundação a cidade vem acolhendo brasileiros de todas as partes e hoje é um verdadeiro "caldeirão" de culturas típicas do país;

\section{2) Vocação para Eventos}

- Por todas as suas qualidades, Brasília já está sendo considerada a capital brasileira do turismo de eventos. A cidade apresenta todos os atrativos e equipamentos turísticos necessários para a realização de um evento de sucesso;

- A cidade oferece dezenas de opções, entre auditórios, salas de conferências e áreas de exposição, sendo que a reforma e ampliação do Centro de Convenções Ulisses Guimarães, a inauguração do Brasil XXI e do Brasília Alvorada Hotel, coloca Brasília num patamar mais competitivo a nível nacional;

- Brasília tem um dos maiores pavilhões de feiras e exposições do país, o Expocenter, com $58.000 \mathrm{~m} 2$, localizado no Parque da Cidade;

- O aeroporto internacional Juscelino Kubitschek é o terceiro maior aeroporto do país. No ano de 1996 recebeu o certificado internacional de qualidade ISO 9001.

\section{3) Localização}

- No centro geográfico do Brasil e da América do Sul;

- A partir de Brasília, o visitante tem acesso fácil e eqüidistante a todas as capitais e principais cidades brasileiras;

- Porta de entrada para o Pantanal e a Amazônia;

- Recebe atualmente 162 vôos diários procedentes das principais cidades brasileiras, facilitando os deslocamentos em curtas distâncias.

\section{4) Rede Hoteleira}


- As grandes bandeiras internacionais da hotelaria estão presentes em Brasília;

- Uma eficiente rede hoteleira local faz com que o realizador de eventos encontre sempre a opção ideal para o que deseja;

- Os hotéis oferecem uma excelente infra-estrutura para a realização de convenções, eventos, seminários e workshops;

- A rede hoteleira da cidade oferece diversas categorias de acomodações, com um total de 17 mil leitos.

\section{5) Facilidade de Deslocamento}

- Por ser uma cidade planejada, com traçado criado pelo grande urbanista Lucio Costa, Brasília oferece grandes vantagens aos organizadores de eventos e a seus participantes;

- Longas pistas, largas e retas criam um trânsito fluente;

- A rede hoteleira está concentrada em locais estratégicos, no centro da cidade e próxima a toda a estrutura de eventos;

- Os principais hotéis estão a 15 minutos do aeroporto, 10 minutos do Setor de Embaixadas e a 5 minutos do Congresso Nacional e do Palácio do Planalto, sede do poder Executivo.

\section{6) Segurança}

O povo brasileiro é conhecido no mundo todo por sua cordialidade e sua alegria. Brasília não é diferente. Além disso, por ser uma cidade nova, que teve seu crescimento planejado, e por ser a sede das representações diplomáticas de todo o mundo e dos três poderes da República: Executivo, Legislativo e Judiciário, Brasília é uma cidade segura para seus moradores e para seus visitantes.

\section{7) Cidade Vitrine}

- Na capital do país, tudo que é feito ganha grande repercussão na mídia. Todas as grandes redes de televisão, os grandes jornais e revistas brasileiros têm cobertura permanente direto de Brasília. 
- Os principais órgãos administrativos e de gestão pública estão sediados na cidade, o que garante agilidade e maior organização para quem está realizando um evento.

\section{8) Lazer \& Gastronomia}

- Opção é o que não falta em Brasília. Como sede das representações internacionais, a cidade absorveu influências das mais diversas culturas do mundo. Por outro lado, o fato de atrair brasileiros de todos os cantos do país faz com que a cidade seja uma verdadeira síntese do Brasil. Em Brasília temos desde sofisticados restaurantes internacionais, até conhecidas festas folclóricas.

- A cidade tem em média 13 habitantes por ABL (Área Bruta Locável) de Shopping Center, um dos índices mais altos do mundo.

- Um povo que vive em uma cidade tão bonita, só poderia ser apaixonado pelas artes. Brasília apresenta ótimas opções de teatros, cinemas, museus, casas de espetáculos, festas e muitas outras atrações;

- Para os apaixonados por esportes, a cidade tem um dos maiores lagos artificiais do mundo, o Lago Paranoá, além de excelente estrutura para prática de esportes como o golfe e o tênis.

9) Clima: O clima na Capital do Brasil é bastante agradável, com temperaturas amenas e períodos bem definidos. Chuvoso de setembro a abril e ensolarado e seco de maio a agosto.

10) Cidade Monumento: Andar por Brasília é passear pela obra de um dos mais geniais arquitetos de todos os tempos: Oscar Niemeyer. Suas brilhantes criações fazem parte da paisagem desta cidade/monumento.

Para refletir-se sobre a vocação turística da Capital, e o futuro do turismo aqui, é importante avaliar-se a situação atual da cidade, seus monumentos, infraestrutura como transporte, serviços e atendimento para que se possa ter um foco, visando sanar possíveis gargalos que estejam barrando o desenvolvimento deste setor.

Mesmo com todos esses pontos favoráveis ao desenvolvimento do turismo da capital, em especial ao turismo de eventos, podemos observar em algumas recentes reportagens em revistas e jornais de circulação na capital, que está havendo uma manifestação quanto à 
situação em que se encontra o patrimônio da humanidade. O Plano Piloto que foi projetado pelo urbanista Lúcio Costa sofre todos os dias agressões e inclusive está correndo o risco de perder o título de patrimônio da humanidade.

Segue abaixo uma lista de algumas das reclamações e dos problemas mais graves que a capital vem passando, conforme noticiado no jornal Correio Brasiliense ${ }^{23}$ e Caderno de Brasília $^{24}$ e que com certeza reflete negativamente no desenvolvimento do turismo na capital:

- Barulho excessivo nos bares, grande fluxo de ambulantes e presença de camelôs nas entrequadras;

- Outro problema antigo, e mais grave contra o tombamento, são os puxadinhos e as invasões de área pública nas quadras comerciais;

- A frota de carros no DF chega a um milhão e cem mil veículos e cresce cerca de $1 \%$ ao ano, resultando excesso de veículos circulando no plano, engarrafamentos, falta de vagas e aumento de oficinas na Asa Norte;

- Situação da W3 sul, muitas lojas fechadas, praticamente abandonadas, e fachadas pichadas e sujas, contribuindo para o aumento de assaltos e depredação do patrimônio;

- Grades e grandes cercas vivas para impedir o acesso aos pilotis também são uma forma de agressão ao tombamento;

- Falta de regulamentação e fiscalização representa a manutenção do caos nas comerciais do plano;

- Aumento da criminalidade e seqüestros relâmpagos;

- Baixa qualidade do atendimento prestado pelos funcionários dos hotéis, restaurantes e do setor de entretenimento e atrativos;

- Falta de divulgação de informações sobre os atrativos disponíveis, folhetos explicativos quanto aos horários e linhas dos ônibus e do metrô;

\footnotetext{
${ }^{23}$ MADER, Helena. Pecados do Plano. Correio Braziliense, Brasília-DF, 01 março de 2009.

${ }^{24}$ AZEVEDO, Isabela. Descaso no trato com turistas. Caderno Brasília, Brasília-DF, 07 junho de 2009
} 
- Dificuldade em encontrar atendentes que falam inglês e que tenham conhecimento sobre a história e os monumentos da capital;

- Falta de cardápios, folhetos informativos e guias da cidade em inglês. O mesmo não é encontrado nos principais museus da cidade;

- De acordo com o Sindicado dos taxistas, dos 3400 taxistas do DF, apenas 100 dominam o inglês;

- Ausência de um Centro de Atendimento ao Turista - o único posto disponível de acordo com a Brasíliatur está localizado no museu da República, na Esplanada dos Ministérios;

- O trade não demonstra motivação com a escolha de Brasília como uma das sedes da copa 2014 (AZEVEDO, 2009);

- De acordo com o GDF - Governo do Distrito Federal, ainda não há programa definido para capacitar funcionários de estabelecimentos ligados ao turismo. "Nossos esforços estão concentrados na implantação do VLT - Veículo Leve sobre trilho na W3 e na reforma do estádio Mane Garrincha" (AZEVEDO, 2009);

- Para Elisângela Machado, gerente de Turismo do CET - Centro de Excelência em Turismo da UNB - Universidade de Brasília, desabafa "Temos que fazer uma profunda mudança cultural no que tange o acolhimento ao visitante. Desafio na mudança cultural no aspecto que diz respeito ao acolhimento e receptividade ao visitante" (MACHADO, 2009 apud, 2009, AZEVEDO).

Mesmo com tantos pontos favoráveis ao desenvolvimento do turismo na capital federal observa-se a necessidade de uma maior preocupação com o planejamento urbano, pois o inchaço, principalmente no plano piloto, já pode ser notado claramente, como o aumento dos engarrafamentos, acidentes de trânsito, violência, aumento do lixo, flanelinhas, camelôs, comercio ilegal, atendimento deficiente aos turistas, entre outros fatores que acabam influenciando negativamente na imagem da capital. 


\subsubsection{Novos projetos e investimentos na Capital do Brasil}

Brasília com seus quase 50 anos sofrerá a maior interferência urbanista dos últimos tempos de acordo com a reportagem Brasília amanhã - uma nova cara, sem mudar a estrutura original, assinada pela jornalista Veiga, 2009 e que para melhorar a fluidez do trânsito o projeto mais ambicioso de todos seria o novo Sistema de transporte, conhecido como veículo leve sobre Trilhos (VLT). Outro projeto para melhorar o trânsito e facilitar a ligação entre as cidades satélites é o via interbairros, que proporcionará geração de empregos, estimulando a criação de novos complexos habitacionais mais organizados e planejados.

Segue abaixo mais uma lista de algumas das prioridades do governo do Distrito Federal, no intuito de melhorar cada vez mais a infraestrutura da cidade para completar seus 50 anos de forma organizada e moderna e receber a copa de 2014 em grande estilo (VEIGA, 2009):

- Integração de vários órgãos e criação de uma pasta que irá fiscalizar todas as atividades urbanas no DF.

- A Secretaria de Ordem Pública irá disciplinar a atuação de flanelinhas, combate aos lava jato irregulares, coibir o uso de estacionamentos públicos para atividades comerciais e acabar com o lixo espalhado pelas ruas;

- Disponibilizar linhas de crédito ou insenções de impostos fiscais para quem fizer melhorias nas fachadas da W3.

- Revitalização da W3, recuperação de praças públicas, e reforma de parquinhos e quadras de esportes

- Construção do veículo leve sobre trilhos (VLT) na W3 sul e norte.

- Projeto de coleta seletiva de lixo para diminuir a quantidade de lixo em caçambas comerciais;

- Aumentar o Turismo de eventos, cívico, ecológico e de negócios em todo o DF de acordo com o Deputado Distrital Roney Nemer;

- Construção dos Centros de Atendimento ao Turista com distribuição gratuita de mapas da cidade em português e inglês; 
- O novo presidente da Brasiliatur, João de Oliveira, e sua nova equipe, prometem maior integração do trade e algumas das prioridades de sua administração será a revitalização da torre de TV, reforma do pavilhão do Parque da Cidade e melhorias na estrutura do Centro de Convenções Ulisses Guimarães;

- O Banco BRB cria serviços diferenciados, como Credtáxi e o crédito consignado, para melhorar a economia do DF e outros setores. A proposta do governador arruda é renovar a frota de táxi da capital, para com isso estimular o turismo;

- O GDF reforçando a tendência de valorizar o verde na capital, reservou mais 70 grandes áreas para a instalação gradativa de novos parques;

- O Governo do GDF prometeu que até 2010, o DF contará com a maior malha cicloviária da América Latina, com aproximadamente 600 km;

- A maior empresa de Shoppings do Brasil será instalada na Capital até o final de 2009, particularmente no lago norte, o investimento de R\$ 180 milhões de reais, gerará 2 mil novos postos de trabalho e receberá um público de aproximadamente $35 \mathrm{mil}$ pessoas/dia;

- Tornar a cidade um modelo de acessibilidade no turismo e referência para todo Brasil para os portadores de necessidades especiais;

- Reativação do Projeto Orla - novo pólo turístico no Lago Paranoá, ao lado da Concha Acústica;

- Implantação de um ônibus turístico no modelo europeu, percorrendo os principais pontos turísticos;

- Projeto Brasília de Braços abertos parceria entre Brasiliatur e Sebrae com o intuito de contribuir com a capacitação técnica e profissionalização do setor;

- Foi solicitado ao governo federal, pelo presidente da Brasiliatur, na época Sr. Roney Nemer, um projeto de estudo de viabilidade para construção de um novo setor hoteleiro, justificando que a taxa de ocupação em Brasília está aumentando e que estão perdendo grandes eventos; 
- Previsão de construção de um túnel entre o Estádio Mane Garrincha e o Centro de Convenções Ulisses Guimarães, de aproximadamente 300 metros, uma vez que o centro será um ponto de apoio durante toda a copa de 2014.

Percebe-se nos tópicos anteriores uma maior preocupação dos dirigentes em tentar consertar as falhas existentes hoje na infraestrutura de Brasília, principalmente porque está próxima de completar seus 50 anos e será uma das cidades sede da Copa de 2014 (Dentre as 17 cidades candidatas a sediar a copa, Brasília foi uma das escolhidas no dia 31 de maio de 2009 na cidade de Nassau, nas Bahamas), conforme divulgado pelos principais meios de comunicação do país. Sendo assim, os governantes almejam melhorar a infraestrutura como todo da capita federal. Contudo, verifica-se um desafio pela frente, uma vez que uma parcela da população não trata a cidade como deveria. Pode-se deduzir que esse comportamento encontrado aqui, de revolta, protesto e descaso pelo patrimônio seja em decorrência de ser o local das decisões políticas nacionais, onde os principais políticos se encontram e a cidade acaba sendo uma vítima das mazelas feitas por alguns políticos. Entretanto para que haja desenvolvimento do turismo na cidade e região essa mentalidade deverá mudar e junto com ela a infraestrutura de apoio, qualificação da mão de obra e receptividade ao turista.

\subsubsection{Perfil dos Turistas de Eventos e Negócios de Brasília}

Com base na pesquisa "Perfil do Turista de BSB" realizada entre 10 a 15 de junho de 2008 pelo Centro de Excelência em Turismo (CET) da Universidade de Brasília e apoio da Empresa Brasileira de Turismo (Brasiliatur) que vamos analisar o perfil do turista da cidade de Brasília, conforme dados abaixo:

- O maior fluxo emissivo para Brasília vem de São Paulo em primeiro lugar com 15\%, seguido de Minas Gerais (13, 97\%), Rio de Janeiro (10,2\%) e Goiás (8,8\%).

- Foi registrado também turistas internacionais, vindo principalmente dos Estados Unidos, Colômbia, Angola, Portugal, Costa Rica, Zimbábue, México, Itália, Espanha e Paraguai. A maioria desses turistas era do sexo masculino, $74 \%$ e $26 \%$ do sexo feminino.

- Os casados superaram a metade dos entrevistos $(54,65 \%)$ e os solteiros tiveram uma quantidade expressiva também, com uma distribuição de 30, 84\%. 
- Mais da metade dos entrevistados possuía graduação (45\%) e com pós-graduação (22, $56 \%$ ), ou seja trata-se de um turista com nível mais elevado e exigente no que se trata de qualidade na prestação de serviços ofertados.

- A faixa etária da maioria dos entrevistados ficou entre 31 a 45/46-65 foram os predominantes (70,07\%), seguidos da faixa etária dos 21-30 anos (23.47\%). Observa-se uma parcela considerável de um público jovem vindo a Brasília fazer negócios ou participar de eventos.

- Em relação ao valor da renda, pouco mais da metade dos entrevistados (50,49\%) ganham entre $\mathrm{R} \$ 2.251,00$ a $\mathrm{R} \$ 9.000,00$ e 21, 59\% ganha entre $\mathrm{R} \$ 901,00$ a $\mathrm{R} \$ 2.250,00$.

- Observa-se um público de alto poder aquisitivo se comparado com a média Brasília. A maior parcela dos entrevistados trabalha no setor público (37\%) contra 32, 92\% nas empresas privadas, seguido de $9,95 \%$ de profissionais liberais.

- Quanto ao motivo principal da viagem dos turistas de negócios, a maioria vem a reunião de trabalho (42,8\%), seguido de trabalho temporário $(19,8 \%)$ e eventos com 17, 5\%. Sobre a organização da viagem a maioria é feita pela própria empresa $(51,4 \%)$, depois vêm as agências de viagem com $21 \%$.

- O meio de transporte mais utilizado é o avião $66,59 \%$, seguido de ônibus $(24,22 \%)$ e carro $(8,07 \%)$. Quanto ao transporte mais utilizado durante sua estada em Brasília foi levantado o táxi o meio mais utilizado $(43,33)$, seguido de metrô $(17,10 \%)$ e carro alugado (10,01\%).

- O turista de negócios permanece em média de 2 a 3 dias na cidade $(42,14 \%)$. A segunda estada mais freqüente é a de 1 dia, com registro de $21 \%$ dos entrevistados, seguido dos que permanecem entre 4 a 5 dias $(13,8 \%)$ e os que permanecem acima de 7 dias com registro de $14,69 \%$.

- Desses entrevistados a maioria se hospeda em hotéis da cidade $(55,98 \%)$, segundo lugar casas de amigos/familiares com 21,42\% e outros $(15,38)$. A viagem sozinho a Brasília foi o registro maior $(59,4 \%)$, seguido aqueles que viajam com executivos da empresa $(27,4 \%)$. 
- Os gastos diários dos turistas estão na faixa de $\mathrm{R} \$ 100,00$ a $\mathrm{R} \$ 300,00 /$ dia $(42,4 \%)$, seguido da faixa abaixo dos R\$ 100,00 (30\%). Os gastos entre R\$ 301,00 a R \$ 500,00 estão na faixa de $13,7 \%$, depois vêm os turistas que gastam acima de $\mathrm{R} \$ 500,00$, apenas $8,4 \%$.

- A maioria dos turistas de negócios, de acordo com os pesquisados, não freqüenta entretenimentos na cidade (71\%). Segundo a pesquisa a maioria dos entrevistados conhece os atrativos da cidade $(70 \%)$.

- Aproximadamente $31 \%$ dos entrevistados passariam o final de semana em Brasília se os preços fossem mais baixos e houvesse promoções. Outros 27,9\% sugeriram maiores informações sobre o que há em Brasília e 17\% sugeriram atrativos culturais para permanência mais prolongada. Em contrapartida a maioria dos entrevistados não despertou interesse por conhecer alguma cidade de Goiás, somente $21 \%$ se interessariam e os municípios mais citados foram Goiânia e Pirenópolis. E mais da metade dos entrevistados (58\%) não têm interesse de voltar a Brasília. Apesar da maioria dos entrevistados ter selecionado a opção não retornar a este destino à maioria deles indicariam a cidade para amigos e parentes.

A pesquisa citada anteriormente contemplou também no questionário a questão da satisfação dos turistas quanto a nossa infraestrutura, atrativos de Brasília, serviços e equipamentos turísticos.

A conclusão que se chegou foi que o turista de negócio revelou, em média, maior satisfação com as variáveis associadas aos atrativos, e menor satisfação com os "equipamentos/serviços turísticos (que nada mais é que atendimento, instalações, preços, qualidade de informações sobre atrativos da cidade). Sendo que as duas últimas variáveis foram as que sinalizaram abaixo da média.

No quadro seguinte, relativo a pesquisa realizada com os turistas de negócios em Brasília, pode-se observar o resumo das maiores e menores satisfações para cada segmento. 
Tabela 04 - Avaliação geral da satisfação do turista de negócios:

\begin{tabular}{|c|c|c|c|c|}
\hline $\begin{array}{c}\text { Ranki } \\
\text { ng }\end{array}$ & Grupo & $\begin{array}{c}\text { Média } \\
\text { do } \\
\text { Grupo } \\
\text { (Variação } \\
\text { de } 0 \text { a 5) }\end{array}$ & $\begin{array}{l}\text { Variável com maior } \\
\text { satisfação no grupo }\end{array}$ & $\begin{array}{l}\text { Variável com menor } \\
\text { satisfação no grupo }\end{array}$ \\
\hline 1 & $\begin{array}{c}\text { Atrativos de } \\
\text { Brasília }\end{array}$ & 3,88 & $\begin{array}{l}\text { Patrimônio histórico/ } \\
\text { Monumentos } \\
\text { arquitetônicos }\end{array}$ & $\begin{array}{c}\text { Sinalização até os } \\
\text { atrativos e diante dos } \\
\text { atrativos }\end{array}$ \\
\hline 2 & $\begin{array}{c}\text { Infra- } \\
\text { estrutura }\end{array}$ & 3,71 & Iluminação pública & Fluidez trânsito \\
\hline 3 & $\begin{array}{c}\text { Serviços e } \\
\text { equipament } \\
\text { os }\end{array}$ & 3,61 & $\begin{array}{c}\text { Qualidade do } \\
\text { atendimento nos } \\
\text { hotéis, pousadas ou } \\
\text { flats }\end{array}$ & $\begin{array}{l}\text { Satisfação com o preço } \\
\text { cobrado nos } \\
\text { restaurantes, bares e } \\
\text { lanchonetes } \\
\text { considerando custo x } \\
\text { benefício. }\end{array}$ \\
\hline
\end{tabular}

Fonte: Pesquisa do Perfil e da Satisfação do Turista de Lazer e de Negócios em Brasília disponível em: www.cet.unb.br acesso em 05 de maio de 2009

A última questão abordada pelos pesquisadores foi a impressão geral de Brasília como destino de negócios e o resultado foi positivo. Aproximadamente $68 \%$ dos entrevistados apresenta boa impressão e para cerca de 19\% a impressão é ótima.

Seguem abaixo as impressões dos turistas entrevistados sobre o destino Brasília:

\section{Impressões positivas de Brasília:}

- Hospitalidade do povo;

- Ser a capital do país;

- Para quem vem fazer turismo é um bom lugar.

\section{Impressões negativas e sugestões:}

- Disponibilizar mais informações a respeito de Brasília e o que ela oferece para lazer e não somente política;

- Melhorias na sinalização, problemas e dificuldades na saída do aeroporto; 
- Falta de informação de como andar em Brasília;

- Os turistas não têm opções a não ser táxi ou ônibus;

- Falta de receptividade das pessoas não o influencia a gastar com a cidade;

- Trânsito ruim e poucas passarelas;

- Faltam atrativos;

- Divulgação ostensiva de eventos e shows;

- Adotar medidas para melhorar o fluxo dos carros;

- Aumentar vagas em hotéis e transporte de qualidade para turista e população local;

- Melhorar o acesso das cidades satélites até Brasília;

- Preços caros demais;

- Mudar toda a estrutura;

- Melhorar hotéis;

- Investir em opções que deixem a cidade menos monótona;

- Precisa-se organizar melhor alguns pontos em Brasília como, por exemplo, a rodoferroviária que é - uma vergonha e a Rodoviária do Plano - que é imunda;

- Criar mais áreas de lazer;

- Necessário melhorar o trânsito;

- Considera Brasília uma repartição pública, não foi feita para lazer;

- Apenas para trabalho;

- Enquanto não houver uma melhoria nos preços, o turismo fica inviável;

- Cidade boa para trabalhar mas não para diversão; 
- Concentra todos os órgãos públicos para serviço público é ótimo;

- Faltam lugares de natureza para ficar no fim de semana;

- Os hotéis deveriam oferecer pacotes de lazer;

- Os táxis deveriam ser da mesma cor para facilitar identificação;

- Deve-se ter mais informativos sobre os horários de funcionamento nos monumentos: táxi sem condição de transitar, muitos velhos.

Nota-se que os pontos negativos estão se sobrepondo aos positivos, então a necessidade de melhorar a infraestrutura da cidade assim como a informação que deveria chegar ao turista é indiscutível, visto que o turista de negócios não está satisfeito com a infraestrutura em geral (equipamentos, serviços e sinalização), nem com o atendimento que aqui está recebendo. 


\title{
3. METODOLOGIA
}

Goode e Hatt (1075 p. 16) consideram método científico:

\begin{abstract}
"Ciência é "um método de aproximação" ao mundo empírico como um todo, isto é, ao mundo que é suscetivel de ser submetido à experiência pelo homem. É além disso, uma aproximação que não se inclina para a persuasão, para o descobrimento da "verdade última", nem para a conversão. É simplesmente um modo de análise que permite ao homem de ciência colocar proposições como: "se".."portanto". Assim, por mais sistemático que seja, qualquer corpo de conhecimento começa com axiomas ou preposisões evidentes "por se mesmas" e termina com deduções originas de tais oxiomas."
\end{abstract}

Ander-Egg (1074, p. 28) complementa em linhas gerais que a pesquisa é um procedimento reflexivo, sistemático, controlado e crítico que permite descobrir novos fatos ou dados, relações ou leis no campo do conhecimento humano.

Para OMT - Organização Mundial do Turismo a pesquisa é um processo, seja indutivo (parte da generalidade empírica dos fatos para a formação de conceitos) ou dedutivo (parte de uma ou de um conjunto de teorias), que deve ser formalizado nas fases que observam no processo de pesquisa em turismo. (SCHLUTER, 2003 p.27)

De acordo com os conceitos explanados anteriormente, seguem os critérios metodológicos utilizados na realização do trabalho:

\subsection{Caracterização da Pesquisa}

Quanto aos objetivos, a pesquisa pode ser:

- Descritiva: Em geral procura descrever fenômenos ou estabelecer relações entre variáveis. Utiliza técnicas padronizadas de coleta de dados como o questionário e a observação sistemática. A forma mais comum de apresentação é o levantamento, em geral realizado mediante questionário e que oferece uma descrição da situação no momento da pesquisa (DENCKER, 2001, p. 124).

No presente estudo foram utilizadas as pesquisas descritiva qualitativa e quantitativa. Quantitativa porque foram usados métodos de aplicação de questionário - o questionário foi elaborado com 8 questões objetivas e enviado ao trade turístico da cidade por meio de e-mail. Qualitativa porque foram levantados e analisados dados em pesquisas, reportagens, artigos e 
monografias e pesquisas relacionadas ao tema. Maiores detalhes sobre a pesquisa poderão ser verificados nos textos a seguir.

\subsection{Definição do Universo da Pesquisa}

Neste estudo foram analisados documentos sobre a cidade de Brasília que apresentam tendências do turismo e do turismo de eventos e negócios, a fim de entender um pouco melhor esse universo e compreender a importância desse mercado para a cidade. Foi realizada ainda uma pesquisa de campo com o trade da cidade, que de acordo com do site do Brasília Convention Bureau e Brasiliatur compreende 60 hotéis, 11 universidades de Turismo, 64 agências de viagens, 10 agências de receptivos, 13 de eventos, 460 de espaços para eventos, 9 restaurantes, 18 companhias aéreas, 14 locadoras de carros, o Ministério do Turismo, a Embratur e Brasíliatur, a ABIH. Brasília Convention Bureau e a ABEOC, totalizando 665 ao se contabilizar empresas, órgãos públicos e associações do trade. Desses 665 foi considerado 1 gestor por empreendimento, ou seja, 665 gestores no total, representando o universo da pesquisa em questão. A partir da definição do universo da pesquisa e a confecção do questionário de 8 perguntas objetivas, o mesmo foi distribuído aos gestores do trade turístico da cidade por email. Considerou-se na pesquisa o universo dos gestores, pois são as pessoas que impulsionam e criam políticas públicas para a dinamização do turismo, portanto, imprescindíveis ao desenvolvimento do turismo na cidade. $\mathrm{O}$ intuito foi ampliar o entendimento sobre a visão desse público em relação à vocação turística da cidade, seus pontos fortes e fracos e compara-las com as pesquisas anteriormente realizadas sobre o tema. Os dados levantados na pesquisa quantitativa e qualitativa foram dispostos em quadros e gráficos para auxiliar na interpretação e análise das informações obtidas, utilizando o método dedutivo de pesquisa.

O método dedutivo utilizado foi o método lógico que segundo Descartes (1969) pressupõe existir verdades gerais já afirmadas e que sirvam de base (premissas) para se chegar através dele a conhecimentos novos de pesquisa, pelo qual, a partir da análise dos dados coletados, foi possível identificar o panorama turístico de Brasília e seu principal público receptor e suas potencialidades e problemáticas. 


\subsection{Procedimento de coleta de dados}

Quanto aos procedimentos técnicos, a pesquisa pode ser:

\section{- Bibliográfica:}

"É fundamentada nos conhecimentos de biblioteconomia, documentação e bibliografia; sua finalidade é colocar o pesquisador em contato com o que já se produziu e registrou a respeito do seu tema de pesquisa" (PÁDUA, 2002, p. 52).

\section{- Documental:}

Difere da pesquisa bibliográfica por utilizar material que ainda não recebeu tratamento analítico ou que pode ser reelaborado. As fontes documentais podem ser documentos de primeira mão conservados em arquivos de instituições públicas e privadas (formulários da EMBRATUR, registro de hóspedes) ou pessoais (diários, relatos de viagem). Além desses, temos os documentos de segunda mão: relatórios (de pesquisa, de empresas) ou dados estatísticos (IBGE). Embora os documentos sejam fontes estáveis de dados e permitam levantamentos históricos, o pesquisador deve verificar se realmente são representativos e procurar interpretá-los corretamente (DENCKER, 2001, p. 126).

Ainda, se admitirmos um conceito mais amplo para a palavra documento, como diz PÁDUA (2002): "é a base de conhecimento fixado materialmente e suscetível de ser utilizado para consulta, estudo ou prova", ou ainda o sentido em que se toma a palavra desde sua origem latina: "documentum: aquilo que ensina ou serve de exemplo ou prova".

Quanto aos meios de investigação:

\section{- Pesquisa de Campo:}

"É a investigação empírica realizada no local onde ocorre ou ocorreu um fenômeno ou que dispõe de elementos para explicá-lo. Pode incluir entrevistas, aplicação de questionários, testes e observação participante ou não" (VERGARA, 2007, p.48).

No presente trabalho foi utilizada a pesquisa documental e bibliográfica. Documental, pois foram analisados dados secundários - pesquisas e trabalhos já realizados anteriormente sobre 
o tema em questão -, referenciando o mercado de turismo, em especial o de turismo de eventos e negócios em Brasília, como forma de verificar e analisar o perfil do turista e sua visão e opinião sobre a infraestrutura da cidade. Bibliográfica porque foram utilizadas pesquisas, textos, monografias, artigos, livros, revistas, jornais e sites relacionados ao assunto (Turismo, turismo de eventos e negócios, planejamento estratégico e segmentação), que são acessíveis ao público em geral. A pesquisa de campo também foi utilizada, pois se viu a necessidade e a importância de se levantar dados junto ao trade turístico da cidade e verificar sua visão e sua opinião a respeito da vocação turística na Capital Federal, uma vez que esse público trabalha diretamente com o turismo na cidade.

\subsection{Plano e Instrumentos de Coleta de dados}

De acordo com DENCKER (2001), a coleta de dados representa a fase do método de pesquisa que tem por objetivo obter informações sobre a realidade, havendo diversas maneiras de realizá-la. Nas ciências humanas, o questionário e a entrevista são os instrumentos mais freqüentes e possuem em comum o fato de serem constituídos de uma lista de indagações que, se respondidas, dão ao pesquisador a informação necessária.

\subsection{Plano de análise de dados}

\subsubsection{Questionário}

A finalidade do questionário é obter, de maneira sistemática e ordenada, informações sobre as variáveis que intervêm em uma investigação, em relação a uma população ou amostra determinada. Essas informações dizem respeito, por exemplo, a quem são os turistas, o que fazem e pensam, suas opiniões, sentimentos, esperanças, desejos, etc. (DENCKER, 2001, p. 146).

Na elaboração do questionário é importante determinar quais são as questões mais relevantes a serem propostas, relacionando cada item à pesquisa que está sendo feita e à hipótese que se quer demonstrar/ provar/ verificar. Isto quer dizer que o pesquisador deve elaborar o 
questionário somente a partir do momento em que tem um conhecimento razoável do tema proposto para pesquisa (PÁDUA, 2002, p. 71).

Neste trabalho foi utilizado o questionário como coleta de dados, elaborado com 8 perguntas objetivas apenas, para proporcionar ao público maior praticidade e rapidez ao responder, uma vez que por meio desse procedimento tanto o questionário como as respostas poderiam ser enviados via internet, agilizando o trabalho e um número maior de respostas. Esse método foi escolhido porque apesar de o autor, à época da realização do presente estudo, não dispor de tempo hábil para distribuir pessoalmente os questionários aos entrevistados, verificou que seria de suma importância na elaboração desse trabalho, para uma análise final sobre a vocação turística da Capital, a opinião do trade.

O estudo proposto através do questionário objetivo foi de muita importância, pois proporcionou pela primeira vez a coleta de dados do trade turístico de Brasília, em relação ao tema "Vocação Turística de Brasília" e suas problemáticas. Através disso foi possível analisar a visão e o conhecimento dos gestores do trade turístico da cidade em relação ao tema proposto.

No início da pesquisa o intuito do autor foi distribuir o máximo de questionários possíveis, uma vez que seu universo ficou definido em 665 gestores do trade. Porém, desse total foi possível a distribuição de apenas 169 questionários no período de 03 de maio a 06 de junho, porque o autor estava trabalhando em tempo integral. Além disso, a demora e desinteresse de uma parcela do público alvo em responder o questionário, curto espaço de tempo entre distribuir e receber o questionário respondido, tabulação e entrega da monografia, acabaram prejudicando a coleta, que poderia envolver um número maior de questionários. Então, desses 169 questionários entregues, obteve-se o retorno de apenas 106, o que corresponde aproximadamente a $16 \%$ do universo amostral de 665 gestores levantados.

Quanto menor o erro maior o tamanho da amostra necessária para inferência sobre a população. Assim, a margem de erro considerada foi de 8,1 pontos percentuais. O intervalo de confiança nos diz que 95\% de todas as amostras possíveis conterão o verdadeiro valor do parâmetro. Essa confiança é utilizada na maioria das pesquisas científicas. (TRIOLLA, 1985)

Neste trabalho foi utilizado um cronograma que visa a disposição do tempo gasto na realização de um trabalho ou projeto, de acordo com as atividades a serem cumpridas, servindo para auxiliar no gerenciamento e controle do trabalho, permitindo, de forma rápida, a 
visualização de seu andamento. Na visão de Carvalho (200, p.109) o cronograma deve estimar o tempo necessário para a realização de cada etapa proposta: elaboração do projeto de pesquisa, montagens de instrumento de coleta de dados, realização de pré-testes dos instrumentos, trabalho de pesquisa, análise dos dados e elaboração do relatório para comunicar os resultados da pesquisa.

O trabalho em questão foi realizado entre os meses de abril e junho de 2009, o que incluiu desde a escolha do tema do projeto o levantamento da literatura e a definição do orientador, dando início ao pré-projeto. Logo em seguida a essa etapa, vieram as pesquisas bibliográficas e documentais. O projeto foi entregue no dia 27 de abril de 2009 e logo em seguida foram aplicados os questionários. Enquanto isso foi feito o desenvolvimento da parte escrita, a análise dos dados secundários - coletados em bibliografias e documentos sobre o tema - e dos dados primários - obtidos através do questionário aplicado ao trade turístico da cidade -, possibilitando assim a elaboração das análises quantitativas e qualitativas e as considerações finais. Após todas essas etapas foram entregues 3 versões da monografia no dia 25 de junho para os integrantes da banca. A apresentação do trabalho foi realizada no dia 28 de julho e a entrega da versão final no dia 10 de agosto de 2009. 


\section{ANÁLISE DOS RESULTADOS DA PESQUISA}

\subsection{Análise dos dados secundários}

Observa-se que o turismo em Brasília está passando por um processo importante de alto conhecimento e amadurecimento. Nota-se uma maior atenção por parte dos dirigentes governamentais e da iniciativa privada em tentar conhecer e estruturar melhor o turismo na capital do país, para atrair mais turistas. Hoje o turismo existente em Brasília praticamente se deve ao turismo de negócios e uma pequena parcela ao Turismo de eventos, isso, levanto-se em conta a pesquisa do Brasília Convention e a pesquisa de Indicadores Econômicos, realizada pelo do CET - Centro de Exelência em Turismo - em parceria com a Brasiliatur, (citada no item 2.5.2 desta monografia Tabela 3 - Motivos da viagem ao DF), soma 64,26\% do total dos turistas. Interessante observar que esse segmento vem crescento em relação ao ano anterior, por exemplo: em julho de 2007 este segmento correspondia a 57\% do total do turistas e em março de 2008 se viu um acréscimo de quase $10 \%$, ou seja, é uma fatia do mercado turístico que está em franco crescimento. Acredita-se que esse crescimento observado, decorre principalmente da melhoria da infraestrutura de eventos da capital, com a reenauguração do Centro de Convenções Ulisses Guimaraes, o que acabou atraindo mais eventos e congressos.

O turismo de lazer ainda corresponde a uma modesta porcentagem, se comparado com o turismo de negócios e eventos. Atualmente representa apenas 4,89\% do total e vem decrescendo se comparado com o ano anterior. Isso talvez seja uma consequência da falta de infraestrutura de apoio, planejamento e divulgação desse segmento para atrair mais turistas de lazer.

Como pode ser observado no item 2.3.2 deste trabalho, a capital federal e seu entorno oferecem diversos atrativos. Desde a arquitetura única da cidade, obras de artes, monumentos históricos, gastronomia diversificada ao turismo ecológico, histórico e rural. O que se observa é a falta de comunicação e divulgação desses atrativos ao seu segmento específico, pois muitos turistas apontaram na pesquisa do Perfil e da Satisfação do Turista da Capital, que falta à capital atrativos, sinalização apropriada para os principais pontos turístico, informações sobre os atrativos, atendimento. Relataram, ainda, que a capital não é lugar para turismo de lazer, somente negócios. Esses foram apenas algumas das observações apontadas pelos turistas entrevistados. 
Para melhor entender o público turístico de Brasília, suas principais características serão analisadas de acordo com a pesquisa Perfil e da Satisfação do Turista. É um público em sua maioria com escolaridade superior e pós graduação, do sexo masculino, de alto poder aquisitivo, vindos principalmente de São Paulo, seguido de Minas Gerais, Rio de Janeiro e Goiás. Percebe-se, aqui, um turista exigente na qualidade dos serviços prestados, e que em sua maioria fica em Brasília apenas dois ou três dias. Que não possuem hábitos de utilizar as atividades de lazer e entretenimento da cidade, mas que demonstram interesse em permanecer um fim de semana na cidade, se pacotes promocionais fossem ofertados, assim como informações da programação cultural e de entretenimento.

Como o público turístico em Brasília, na sua maioria é o de negócios e eventos, faz se necessário saber os principais locais que visitam, para poder utilizá-los como meio de divulgação dos outros atrativos e da programação cultural, incentivando, assim, a visitação dos lugares menos frequentados. Nesta pesquisa ainda foi detectado que o turista de eventos e negócios visita principalmente a Catedral, os shoppings centers e a praça dos três poderes, ou seja, esses locais seriam bons meios de comunicação com o segmento.

Por outro lado, um importante indicador da atividade preferida do turista de lazer, percebido na pesquisa, foi o city tour, se sobresaindo inclusive sobre atividades consideradas de pontencialidade como o turismo religioso, rural e atividades naúticas. Isso demonstra que é importante a sistematização e operacionalização de um city tour, bem organizado pelos principais pontos turísticos da cidade. Assim como mapas turísticos em mais de duas línguas, sinalização em inglês dos principais pontos turísticos, shooppings, hotéis, restaurantes, dos pontos de desembarque, como aeroporto e rodoviária, e, no caminho destes àqueles, facilitando e atraindo a visitação dos turistas brasileiros e estrangeiros.

Desta maneira, a análise da realidade da hotelaria na capital é imprescindível para a verificação do desempenho do setor hoteleiro e do turismo na capital federal. De acordo com os dados obtidos no site do Brasília Convention Bureau, a cidade possui 47 hotéis que juntos somam 8.700 apartamentos, o que corresponde a 18 mil leitos aproximadamente. A listagem abaixo se refere apenas aos principais hotéis da cidade, mas, no entanto, se percebe que a mesma não está atualizada, pois não contabiliza os apartamentos do Hotel Sonesta, rede internacional, atualmente em funcionamento. Isso demonstra que o número de hotéis e leitos pode ser superior ao informado abaixo. 
Quanto à média de ocupação anual da rede hoteleira, com base nas informações a seguir, é de $70 \%$ no período de segunda a quinta-feira, caindo para $40 \%$ de sexta a domingo. Interessante ressaltar que Brasília conta com uma ocupação média relativamente alta, como demonstrado na pesquisa, e que a maioria desse público é o turista de eventos e negócios que, como se viu, normalmente não utiliza os equipamentos de lazer e entretenimento da cidade. Pode-se deduzir que a não utilização desses equipamentos ocorra devido ao fato de o motivo da viagem ser a realização de negócio, ou da falta de divulgação, estratégia de marketing, estruturação e maior facilidade para que desperte o interesse em conhecer os pontos turísticos e no lazer oferecido pela cidade.

Tabela 05 - Taxa de ocupação dos hotéis da cidade de Brasília:

\begin{tabular}{|c|c|c|c|c|}
\hline \multirow[t]{2}{*}{ HOTEL } & & & \multicolumn{2}{|c|}{ Taxa de Ocupação } \\
\hline & Aptos & Leitos & $2^{\mathrm{a}}$ a $5^{\mathrm{a}}$ & $6^{\mathrm{a}}$ a Dom. \\
\hline Alvorada Hotel & 123 & 253 & $70 \%$ & $40 \%$ \\
\hline Blue Tree Park & 395 & 598 & $90 \%$ & $70 \%$ \\
\hline Blue Point Suites Bonaparte & 115 & 351 & $90 \%$ & $40 \%$ \\
\hline Carlton & 195 & 420 & $85 \%$ & $25 \%$ \\
\hline Casablanca & 58 & 174 & $70 \%$ & $20 \%$ \\
\hline Comfort Inn Taguatinga & 105 & 200 & $55 \%$ & $30 \%$ \\
\hline Comfort Suítes Brasília & 186 & 500 & $58 \%$ & $40 \%$ \\
\hline Eron Brasília & 181 & 371 & $70 \%$ & $35 \%$ \\
\hline Grand Bittar & 147 & 294 & $80 \%$ & $40 \%$ \\
\hline Garvey Park & 86 & 159 & $70 \%$ & $40 \%$ \\
\hline Hotel Nacional & 347 & 794 & $70 \%$ & $50 \%$ \\
\hline Kubitschek Plaza & 389 & 800 & $80 \%$ & $20 \%$ \\
\hline Manhattan Plaza & 314 & 859 & $80 \%$ & $20 \%$ \\
\hline Meliá & 594 & 780 & $80 \%$ & $65 \%$ \\
\hline Mercure Brasília & 358 & 500 & $80 \%$ & $50 \%$ \\
\hline Metropolitan Flat & 133 & 420 & $80 \%$ & $50 \%$ \\
\hline Monumental Bittar & 111 & 272 & $80 \%$ & $20 \%$ \\
\hline Naoum Plaza & 187 & 402 & $80 \%$ & $40 \%$ \\
\hline Parthenon & 327 & 584 & $86 \%$ & $64 \%$ \\
\hline Phenícia Bittar Hotel & 130 & 260 & $80 \%$ & $50 \%$ \\
\hline Quality Lakeside & 165 & 357 & $80 \%$ & $40 \%$ \\
\hline
\end{tabular}




$\begin{array}{ccccc}\text { San Marco } & 256 & 562 & 70 \% & 20 \% \\ \text { Saint Paul } & 340 & 573 & 80 \% & 40 \% \\ \text { Saan Park } & 72 & 148 & 70 \% & 40 \% \\ \text { Sia Park } & 50 & 124 & 80 \% & 60 \% \\ \text { Sonesta Brasília } & 125 & 300 & & \text { Em Construção } \\ \text { TOTAL } & \mathbf{6 . 0 2 5} & \mathbf{1 1 . 8 5 7} & & \\ \text { Hotel } & \text { Aptos } & \text { Leitos } & \text { Taxa de Ocupação } \\ \text { Albergue da Juventude } & 20 & 120 & & -\end{array}$

Fonte: Disponível em http://www.brasiliaconvention.com.br/eventos_capacidade_hoteleira.php acesso em $11 \mathrm{de}$ junho de 2009

\subsection{Análise dos dados primários}

Foram aplicados 106 questionários no perído de 03 de maio a 06 de junho os gestores das empresas do ramo do turismo, como restaurantes, locadoras de carros, agências de viagens e turismo, agências de eventos e cerimoniais, hotéis, Brasília Convention Visitors Bureau, órgãos públicos como Embratur, Ministério do Turismo e ABEOC.

Esperava-se conseguir um número bem maior de questionários respondidos, pois foi utilizado o método de questionário estruturado, com perguntas fechadas, justamente para não tomar muito tempo do entrevistado, uma vez que as pessoas estão num ritmo de vida muito atribulado e corrido. Porém, muitas pessoas não demonstraram interesse ou não se prontificaram a responder o questionário. Foram distribuídos 169 questionários, obtendo-se retorno de 106 respondidos.

O questionário aplicado teve a intenção de levantar a visão do trade sobre o turismo na capital e principalmente detectar qual seria sua opinião quanto a vocação da cidade para o turismo de eventos e negócios, sendo esse o segmento que se mostra em grande crescimento no Brasil e mundo, e um importante meio de fomento e desenvolvimento do turismo como todo. Como comentou João Luiz dos Santos Moreira, presidente da Confederação de Convention Visitor Bureau, em entrevista ao Jornado de Turismo ${ }^{25}$, "o país, em 2008, registrou $22 \%$ a mais de eventos que 2007. Isso comprova que o turismo de negócios e eventos cresce a cada ano no mundo, se considerarmos o crescimento no Brasil"

${ }^{25}$ PERES, Adoniran. Trade comemora $7^{a}$ posição do Brasil no ranking da ICCA. Jornal de Turismo, Brasília, 25 a 31 de maio de 2009. 
De acordo com os indicadores Econômicos das Viagens Corporativas, estudo realizado pela USP - Universidade de São Paulo ${ }^{26}$, o turismo de negócios e eventos no Brasil movimenta 33, 6 milhões de reais, gera 260, 5 mil empregos e as empresas gastam, por ano, R\$ 15, 5 milhões em viagens. Em 2006, o segmento de transporte áereo consumiu 59, 4\% da receita; o segmento eventos representou $6,2 \%$, a hospedagem $29,1 \%$ e a locação $5,1 \%$. Já no mundo o segmento de turismo de eventos e negócios movimenta por ano aproximadamente US\$ 4 trilhões. No Brasil o setor envolve cerca de 80 milhões de participantes/ano, gerando mais 2, 9 milhões de empregos, contabilizando os diretos e indiretos, envolvendo mais de 54 setores da economia.

\section{Seguem os resultados da pesquisa em gráficos:}

O gráfico 1 demonstra o grau de escolaridade. Surpreendentemente a maioria dos intrevistados eram pós graduados, correpondendo $28 \%$ do total. Em seguida se destacam os que possuem o $3^{\circ}$ grau incompleto com $23 \%$. Observa-se que os que possuem $3^{\circ}$ grau completo e os pós graduados representam quase a metade dos entrevistados, $42 \%$. Pode-se dizer, assim, que os profissionais da área estão mais preocupados com a qualificação, buscando se especializar e aperfeiçoar seus conhecimentos. Isso talvez se deva ao aumento da concorrência e da vinda de empresas mais capacitadas para a operação do turismo no DF. Nota-se, que redes internacionais de hotelaria vêm se instalando na cidade, como a rede Sonesta, Comfort, Meliá e Mercure o que acaba ocasionando a demanda por mão de obra mais qualificada.

\footnotetext{
${ }^{26}$ Disponível: http://www.abeoc.org.br/200801221736.php acesso em 28 de junho de 2009
} 


\section{Grafico 1 - Grau de escolaridade}

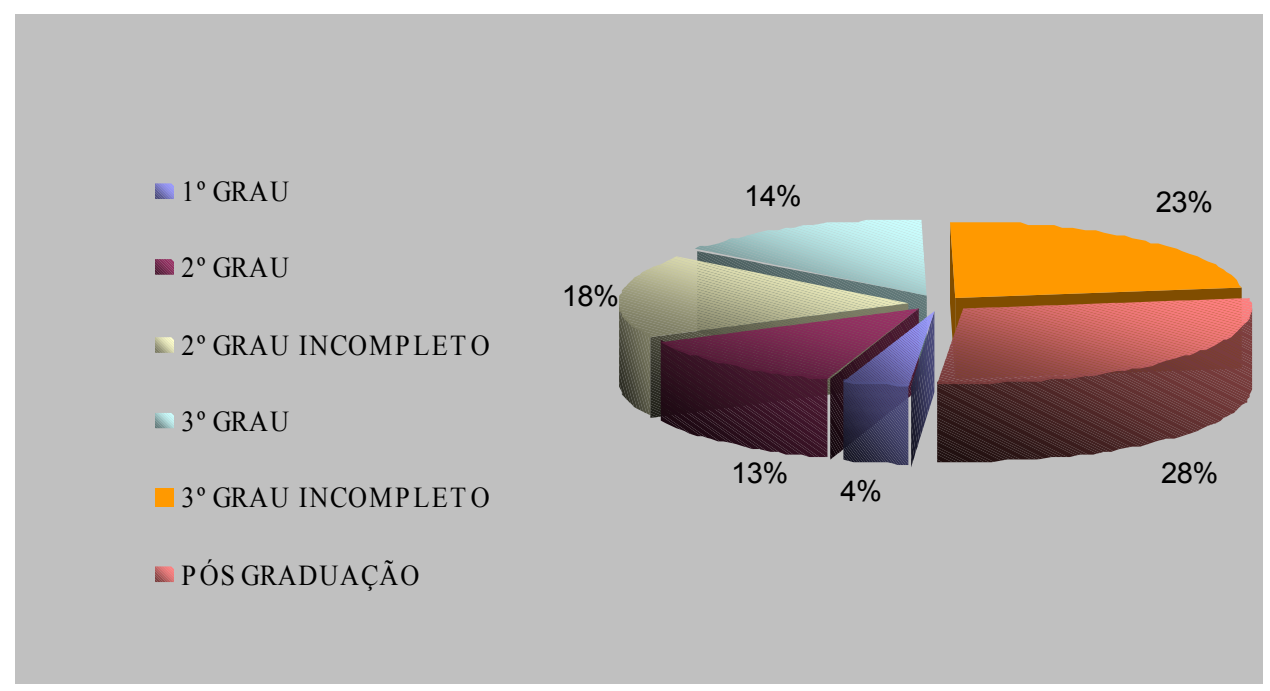

O gráfico 2 apresenta a área em que o entrevistado atua. Os funcionários públicos foram a maioria, 24\% do total. Em segundo lugar, com uma pequena diferença, as agências de viagem com $23 \%$ contra apenas $16 \%$ dos hotéis. Percebeu-se uma interessante participação dos órgãos públicos federais, os quais demonstraram uma grande preocupação e importância da pesquisa para o futuro do turismo na capital. Uma vez que a cidade está prestes a sediar um evento esportivo de nível mundial e, se não se preparar, melhorar a infraestrutura e qualificar a mão de obra, poderá colocar em risco a imagem da capital como destino turístico.

\section{Gráfico 2 - Área do Trade em que o entrevistado atua}

- ÓRGÃO PÚBLICO

- AGÊNCIA DE VIAGEM

- HOT EL

- LOCADORA DE CARRO

CIA. AÉREA

- AGÊNCIA DE RECEPTIVO

- UNIVERSIDADE

EVENTOS

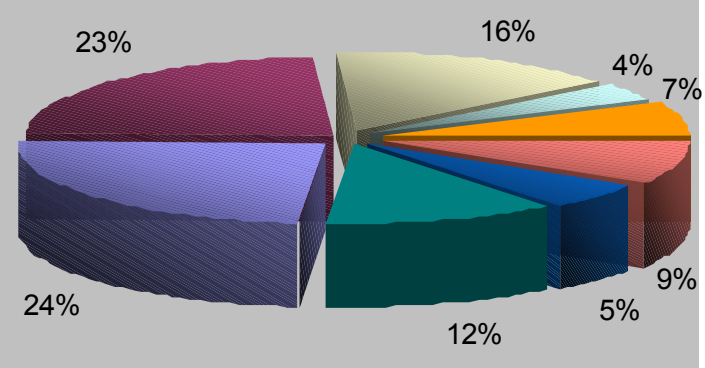


O gráfico 3 representa a opinião do trade quanto ao tipo de turista que a capital mais recebe. Em destaque ficaram os turistas de eventos e negócios. Outra parte dos entrevistados indicaram somente o turista de eventos, com 15\% do total, e o turista de negócios com 13\%. O turismo de eventos e negócios contabilizou mais da metade na opinião do trade e uma pequena parcela indicou o turista cívico, cultural, místico e religioso.

Se se levar em conta o turismo de eventos juntamente com o de negócios, a pesquisa mostra que, como ocorrido na pesquisa na Pesquisa do Brasília Convention em 1996 e na pesquisa Indicadores Econômicos, realizada pelo CET e Brasíliatur, onde se levantou que o turista de negócios e o de eventos são os turistas que a cidade mais recebe, o trade local chegou à mesma conclusão, porém de acordo com a pesquisas acima o turista de negócios ainda é o turista predominante na cidade, desmistificando a questão que Brasília seria a capital de eventos do país, pois a metade dos turistas da cidade vem a negócio e não a ventos, congressos. Já na pesquisa com os gestores do trade o turista de negócio ficou na terceira posição. Isso se deve às diversas propagandas, trabalho e projetos vendendo a cidade como destino de eventos e também um desejo do trade em tornar a cidade na Capital de eventos do pais. Mas como já foi demonstrado nesse trabalho a cidade de São Paulo continua imbatível nesse quisito, dominando o mercado de evento em aproximadamente $75 \%$, realizando mais de 90 mil eventos ano.

Importante lembrar que este turista de negócios, que vem a Brasília, como já relatado neste trabalho, é um público de alto poder aquisitivo, em sua maioria masculino e que normalmente não utiliza os equipamentos de lazer e entreterimento da cidade, reforçando, então, a idéia de uma fatia, ou segmento estratégico e em potencial a ser explorada pelo trade, com o intuito de estimular esse público a usufruir mais os atrativos culturais da cidade e aumentar seu tempo de permanência na capital. 


\section{Gráfico 3 - Tipo de turista que Brasília mais recebe na opinião do entrevistado:}

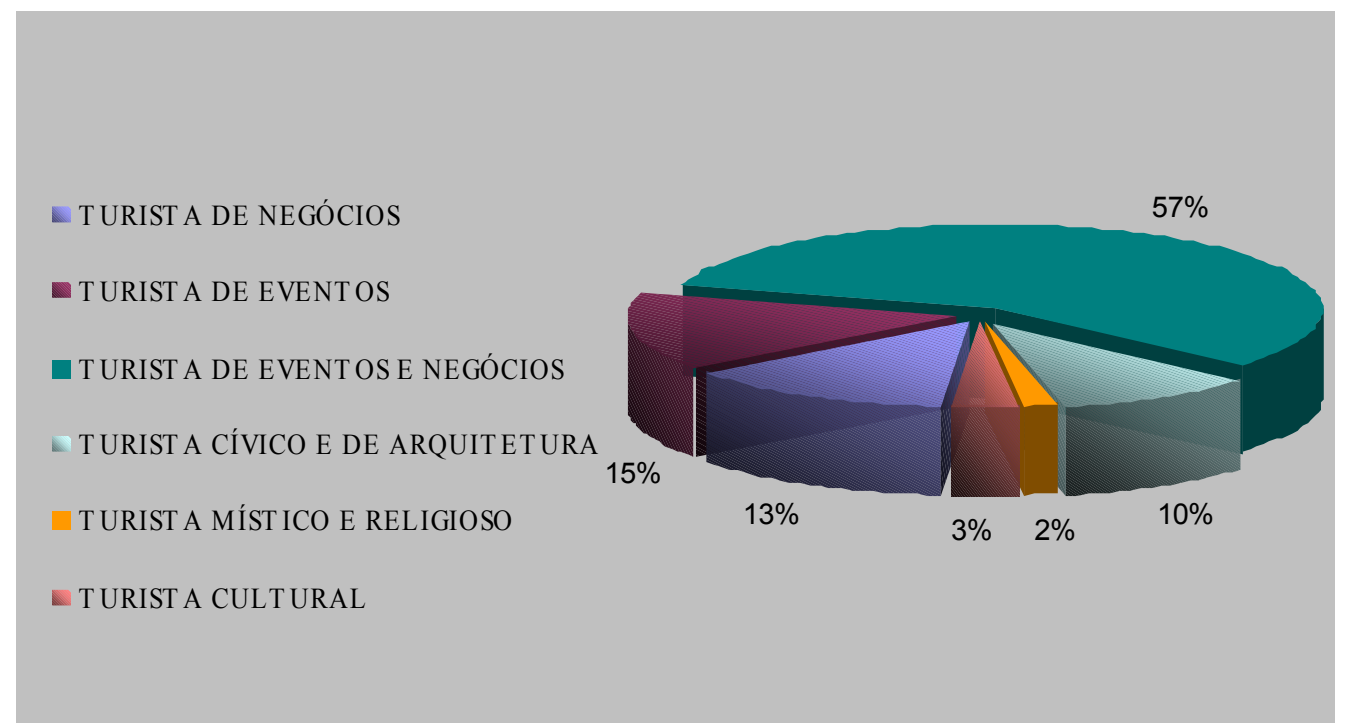

No gráfico 4 abordou-se a principal deficiência na infraestrutura de eventos de Brasília na opinião dos entrevistados, onde o transporte deficitário correspondeu a $32 \%$ do total. $\mathrm{O}$ número insuficente de leitos ficou em segundo lugar com $18 \%$ e em seguida veio a falta de mão de obra especializada com $16 \%$.

Como já demonstrado anteriormente neste trabalho, a pesquisa de Perfil e Satisfação do turista no DF, também demonstrou nível abaixo da média nos quesitos infraestrutura, principalmente sobre as variáveis "transporte em Brasília (táxi, ônibus, metrô)". Contudo no item 2.3.4 deste trabalho, verifica-se a previsão de investimentos na melhoria do transporte público, como a construção do VLT - veículo leve sobre trilhos, que ligará o aeroporto ao Plano Piloto, melhorando o acesso dos turistas aos principais pontos turísticos da cidade. A via interbairros também melhorará a fluidez do trânsito. A implantação de ônibus turístico no modelo europeu, percorrendo os principais pontos turísticos da cidade, melhorará o acesso dos turistas aos atrativos. Percebe-se assim uma maior preocupação por parte dos governantes no quisito transporte, pois sem essa modalidade não existe turismo.

Interessante ressaltar que Brasília durante a semana, principalmente entre terça e quinta-feira possui uma taxa de ocupação muito alta, chegando a quase $100 \%$ de acordo com o Brasília Convention Bureau, o que dificulta para os visitantes encontrar disponibilidade na hotelaria da capital durante a semana. Isso também reflete na captação de eventos, pois se não houver leitos disponíveis e mão de obra qualificada, falando inglês e atendendo bem o turista nacional e internacional, o mesmo não retornará e ainda divulgará a péssima experiência. $\mathrm{O}$ 
Projeto Brasília de Braços abertos, parceria entre a iniciativa pública, privada e Sebrae para capacitação da mão de obra do setor, é uma esperança de melhorar a qualidade no atendimento e na prestação do serviço prestado.

Observa-se que os entrevistados estão cientes de que, para ter um turismo profissional precisa-se ter um atendimento de excelência, ter infraestrutura e transportes adequados para os moradores e turistas, com informações turísticas e qualidade na prestação de serviço como um todo. Pois, de acordo com a pesquisa do perfil do turista que visita o DF, a maioria dos que procuram Brasília são pessoas graduadas e pós graduadas, portanto, acredita-se ser pessoas informadas, formadoras de opinião e exigentes.

\section{Gráfico 4 - A principal Deficiência na infraestrutura de eventos de Brasília na opinião do entrevistados:}

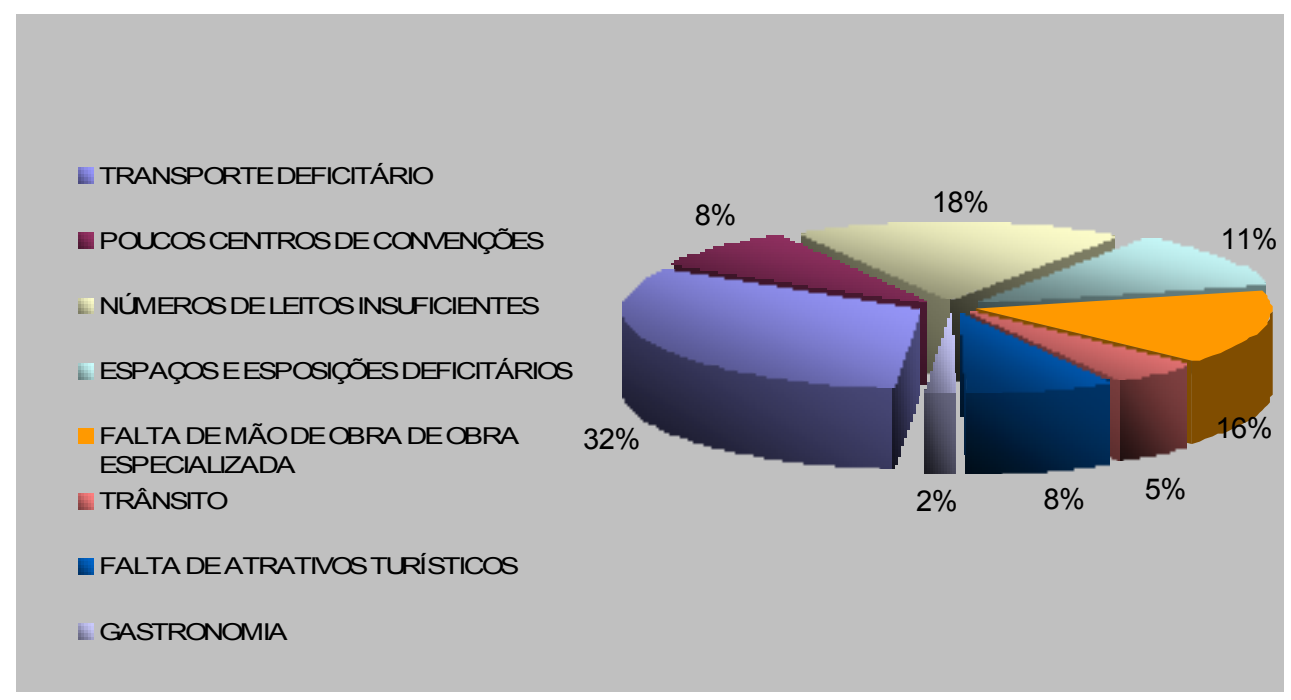

Quando se fala de vocação turística de Brasília, a maioria esmagadora acredita que a vocação da capital federal é o turismo de eventos e negócios, com a expressiva fatia de $60 \%$ do total dos entrevistados, como pode ser observado no próximo gráfico de número 5.

Em segundo plano, com 16\%, aparece o turismo cívico e de arquitetura. Pode-se observar aqui que o próprio trade não acredita na potencialidade do turismo cultural da cidade, e vê somente no turismo de eventos e negócios uma possibilidade para a atração de turistas que vêm em busca de cursos, seminários, congressos e negócios em geral.

Como a Brasíliatur e seus consultores de turismo estão sistematizando o turismo na capital, criando segmentos específicos como o turismo cívico, de arquitetura, jurídico, rural, aventura 
e o roteiro Athos Bulcão, serão oferecidas atrações diversificadas a esses segmentos. Contudo cada segmento deve ser trabalhado de forma diferenciada, focada, simples e objetiva, para que o objetivo seja atingido, atraindo os turistas de forma eficaz. De nada adianta a criação de roteiros se os mesmos não forem implementados, divulgados estrategicamente, com objetivos e metas bem definidos.

Talvez o turismo de negócios e eventos seja o meio de estimular o visitante de Brasília a conhecer melhor a capital e seus atrativos, uma vez que a cidade já recebe um número considerável desse turista, podendo ser o mesmo um público potencial para o fomento do turismo cultural e de lazer na cidade.

\section{Gráfico 5 - Principal vocação turística de Brasília na opinião do entrevistado:}

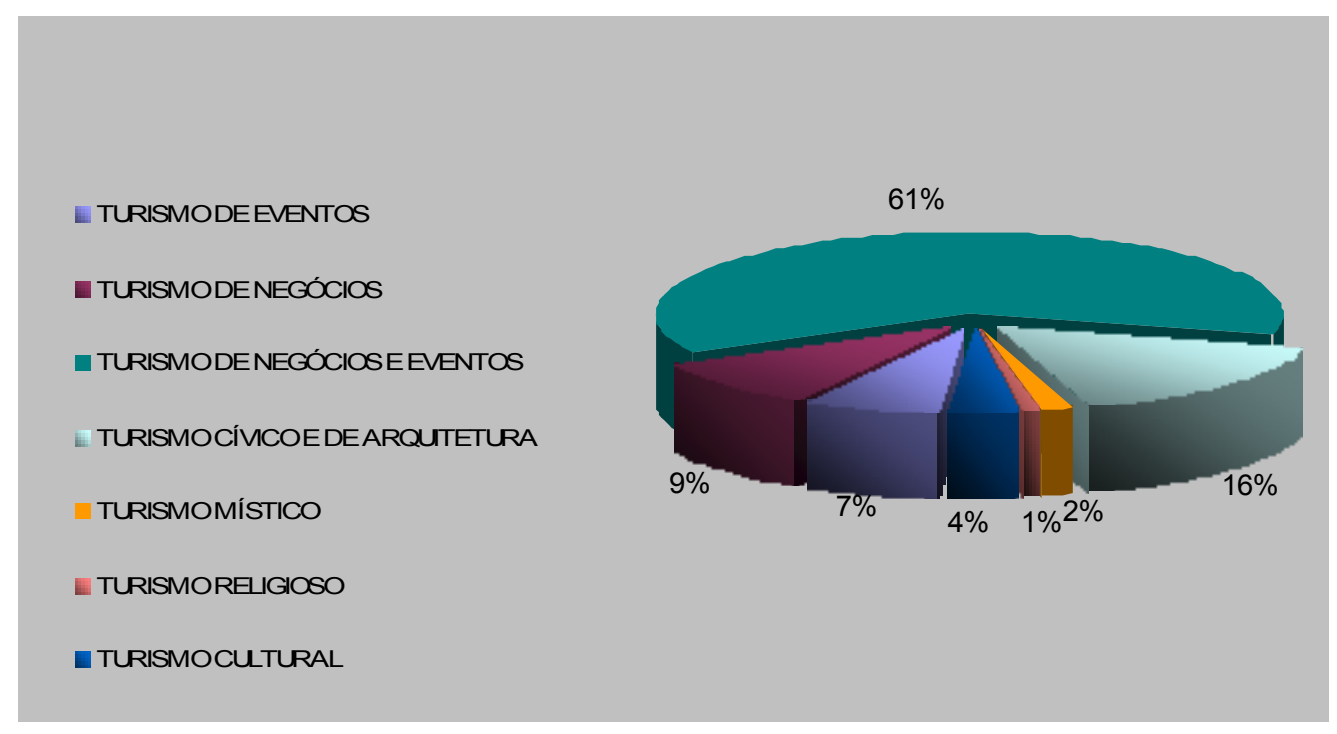

O gráfico 6 está relacionado à pergunta: Você acredita que o trade turístico em Brasília (que seria as agências de viagens e eventos, hotéis, pontos turísticos e atrações no entorno) trabalha de forma integrada?

A maioria, como se pode observar no gráfico abaixo, não acredita que o trade trabalha de forma integrada, 83\%. Esta é uma informação preocupante, pois sem a integração, colaboração entre si, o turismo na cidade se deparará com uma difícil situação, pois o hóspede necessita de informações corretas para que desperte seu interesse nos pontos turísticos, restaurantes e atrações culturais. 
Essas atitudes de informação e atendimento geram divisas, movimentação de renda e ao mesmo tempo marketing e negócios. Se esse turista ficar satisfeito, conhecer as atrações, for bem atendimento e informado, com certeza indicará para outros, fomentando o turismo. Por isso é de suma importância que o trade se fale, se reúna, troque experiências e informações para que as necessidades e possíveis gargalos sejam sanados, e através disso atraiam novas oportunidades de negócios para o destino.

De acordo com o novo Presidente da Brasíliatur, João Oliveira ${ }^{27}$, que se comprometeu com o Brasília Convention Bureau, a partir de agora as ações serão integradas: "Todo trabalho será realizado em parceria mútua com o trade turístico".

Observa-se aqui o início de uma nova fase para o turismo na capital federal, pois os dirigentes estão vendo a importância da integração do trade da cidade e entorno para o sucesso de todos. E se tudo correr como planejado, integração do trade, implementação dos novos roteiros, melhoria dos transportes públicos, infraestrutura e qualificação da mão de obra, o turismo no DF com certeza irá acontecer de verdade e de forma profissional.

\section{Gráfico 6 - Integração do trade turístico de Brasília:}

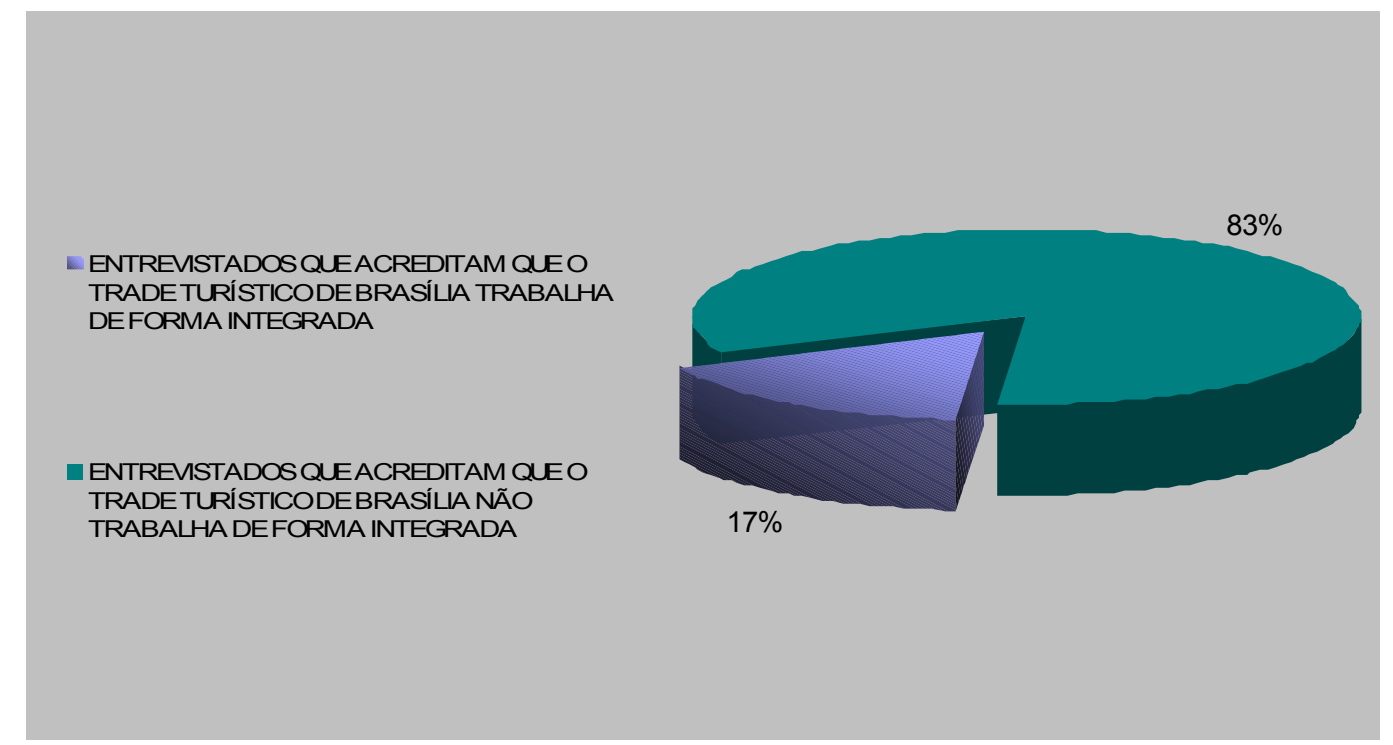

\footnotetext{
${ }^{27}$ Disponível em: http://www.jornaldeturismo.com.br/noticias/df/24727-brasiliatur.html, acesso em 30 de maio de 2009
} 
Na sétima e última pergunta, foi questionado qual seria a principal dificuldade ou deficiência para que Brasília se destacasse como destino turístico no Brasil, cujo resultado se observa no gráfico 7.

A maioria, 36\%, acredita que a falta de estratégias para se posicionar seria a principal dificuldade. Em segundo lugar, com 18\%, um dos motivos seria a falta de divulgação da cidade. Logo em seguida a falta de atrações turísticas de lazer e entretenimento com 14\%.

A falta de estratégia para se posicionar foi a opção mais apontada pelo trade, imagina-se, portanto, que a atual situação do turismo na capital decorre dessa falta de posicionamento, em que não há uma definição clara de sua atuação no mercado turístico. Assim, se faz necessário organizar e gerir os segmentos, visando melhorar a comunicação promocional junto ao seu público alvo. E essa criação dos roteiros turísticos da capital apresenta uma tentativa de reorganização do turismo, focando-se nos públicos alvos específicos. Após a definição dos roteiros por meio da oferta da capital e do entorno, automaticamente se define a demanda na qual se pretende atingir, porém de nada adianta se os equipamentos de apoio ao turismo não forem melhorados e a mão de obra não for treinada e preparada para receber o turista adequadamente. E para se posicionar de maneira eficaz é indispensável o desenvolvimento de diferenciais significativos nos seus atrativos e serviços prestados, em relação aos oferecidos pelos destinos concorrentes que atuam no mesmo mercado.(KOTLER; HAYES; BLOOM, 2002)

É importante notar que algumas cidades já nascem com a vocação turística bem definida, como por exemplo o Rio de Janeiro e outras cidades turísticas. Algumas cidades como Boston, que segundo Bruce Ehlich e Peter Dreier (1999) se transformou em uma das cinco mais visitadas dos Estados Unidos, puramente por acidente, não sendo resultado de um planejamento cuidadoso pelas iniciativas privadas e públicas. Porém, mesmo assim é necessário um planejamento neste estágio em que ela se encontra para que seja preservado esse sucesso. Sendo uma das 5 cidades mais visitadas dos EUA, os visitantes a procura por diversos motivos e os principais são: negócios, universidades, eventos especiais como a maratona de Boston, para ver cidades coloniais e históricas, eventos universitários como formaturas, fazer compras nos principais shoppings, visitar os milhares de museus ou para assistir teatros e orquestras. 
Se os órgãos públicos juntamente com a iniciativa privada continuarem trabalhando de forma integrada, implementando todos os projetos e investimentos previstos neste trabalho, de forma consciente, eliminando as falhas e focados no público alvo, de forma diferenciada, estratégica e planejada, certamente consolidarão o turismo de eventos e negócios na capital federal e ainda possibilitarão o desenvolvimento do turismo como todo, aumentando o interesse e a visitação nos atrativos originais.

Gráfico 7 - A principal dificuldade ou deficiência para que Brasília se destaque como destino turístico no Brasil na opinião dos entrevistados:

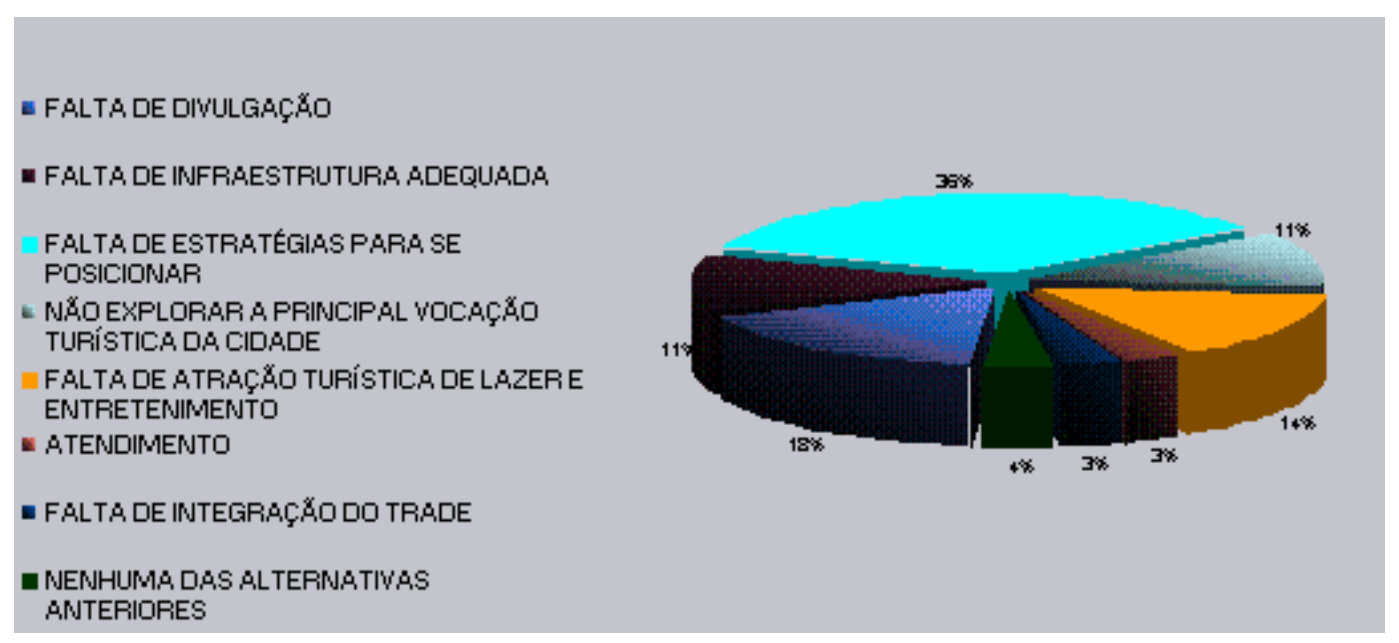




\section{CONSIDERAÇÕES FINAIS}

O mercado turístico na Capital Federal encontra-se em franco desenvolvimento e em fase de reestruturação e investimentos. A cidade oferece atualmente diferentes atrativos aos turistas que vão desde turismo cultural (Cívico, jurídico e arquitetônico) e ecológico ao gastronômico, rural, religioso e místico. Mesmo com todas essas opções turísticas, o turismo de negócios e eventos configura-se ainda como o principal segmento do turismo e um setor econômico representativo e promissor na cidade de acordo com as pesquisas realizadas pelo CET Centro de Excelência em Turismo em parceira com a Brasíliatur e a pesquisa do Brasília Convention \& Visitors Bureau.

Brasília, mesmo sendo uma cidade jovem, moderna, conhecida internacionalmente pelo seu traçado urbanístico único, considerada um museu a céu aberto, está cheia de histórias para contar, desde sua construção, que foi em tempo recorde, aos dias atuais. Foi tombada como Patrimônio da Humanidade - Unesco, o que demonstra sua importância arquitetônica e histórica. Possui ainda, cultura diversificada, vida própria, várias opções de restaurantes e diversos setores em desenvolvimento, um deles é o turismo que vem despontado e crescendo vertiginosamente nos últimos anos. Isso quer dizer que mesmo jovem, centro do poder e das decisões do País, já está amadurecida, e, apesar de ser considerada por alguns um lugar sem identidade e opções atrativas, Brasília proporciona uma gama de serviços e lazer próprios e variados.

É devido a isso tudo e a importância cultural e arquitetônica de Brasília para a humanidade e o crescimento do turismo de eventos e negócios no Brasil e no mundo que se justifica o presente estudo, que teve como objetivo fazer um estudo sobre o turismo em Brasília, visando identificar a vocação turística da cidade, baseado na percepção do trade. Os objetivos específicos foram os seguintes: Levantar as ações, projetos e planos a serem executados pela iniciativa pública e privada para alavancar Brasília como destino turístico e suas atuais deficiências; analisar o perfil do turista e o turismo de Brasília e identificar os segmentos turísticos mais representativos Capital Federal. Dessa forma, os objetivos foram alcançados pela metodologia de pesquisa quantitativa e qualitativa. Os dados quantitativos foram levantados por meio de questionário objetivo aplicado ao trade turístico da cidade de Brasília, indagando sobre a atual situação do turismo na capital, em especial o turismo de eventos e a principal vocação turística da cidade. Destaca-se assim o problema da pesquisa: Qual a percepção do trade quanto à vocação turística de Brasília? 
Assim, a pesquisa quantitativa aplicada confirmou a hipótese positiva da pesquisa, qual seja, que a maioria do trade percebe como vocação turística de Brasília o Turismo de Eventos e Negócios. Confirma ainda que os gestores do trade ainda têm uma visão um pouco distorcida da atual situação do turismo na Capital do Brasil, pois posicionaram o turista de negócios como o terceiro tipo de visitante que mais frequenta Brasília e na verdade o turismo na cidade existe graças ao turista de negócios e não ao de eventos. Além disso, foi confirmado por meio da pesquisa que o trade entende como umas das principais deficiências e problemas para o desenvolvimento do turismo no DF o transporte deficitário, a falta de união do trade e de estratégias para se posicionar no mercado turístico. Ou seja, Brasília ainda não tem uma imagem turística bem definida perante o público e o mercado turístico.

Os dados secundários, que são os dados qualitativos, foram levantados por meio de pesquisas realizadas anteriormente pelo trade, como a Pesquisa do Perfil e da Satisfação do Turista de Lazer e Negócios de Brasília e a de Indicadores Econômicos para o Planejamento do Turismo no DF, ambas realizadas pelo CET e Brasíliatur, as quais identificaram que a cidade precisa urgentemente de investimento e melhorias no que tange à segurança, transporte, sinalização adequada, treinamento e capacitação da mão de obra do trade e também maior cuidado e preservação do Patrimônio da Humanidade.

Por outro lado, se identificou em pesquisas bibliográficas, entrevistas em revistas e jornais, monografias e sites da internet que existem vários projetos que irão fazer da cidade um dos principais destinos de negócios e eventos no Brasil, e quem sabe impulsionar também o turismo cultural e de lazer na capital. Até 2014, data da realização da Copa do Mundo, da qual Brasília será uma das cidades sedes, ocorrerão vários investimentos na melhoria da infraestrutura do transporte público, fundamental para o desenvolvimento do turismo, assim como reforma e modernização do aeroporto, construção da nova rodoviária, revitalização da W3 sul e norte, construção do VLT - veículo leve sobre trilhos, reforma do Estádio Mané Garrincha, implementação de roteiros turísticos, ônibus turísticos no modelo europeu, criação do CAT - Centro de Atendimento ao Turismo, investimento na infraestrutura da orla do Lago Paranoá e capacitação da mão de obra turística local entre outros.

Contudo, após todos os dados demonstrados anteriormente neste trabalho, que Brasília conta com um potencial turístico considerável, devido sua própria origem e por ser a Capital do país, porém, para que a mesma se consolide e tenha sucesso, todos os projetos devem ser concluídos conscientemente, integrando o trade com a iniciativa pública, fazendo-se 
primordial a criação, e um posicionamento mais competitivo, do produto turístico Brasília nas prateleiras das agências, com estilo próprio e personalidade definida.

Sendo assim, foi identificado por meio da pesquisa de campo que a vocação turística de Brasília, segundo a percepção do trade é o turismo de eventos e negócios. 


\section{REFERÊNCIAS}

\subsection{Bibliográficas}

ACERENZA, Miguel Angel. Administração do turismo: conceituação e organização. Trad. Graziela Rabuske Hendges - Bauru: EDUSC, 2002

ANDER-EGG, Ezequiel. Introduccion a las Tecnicas de Investigacion social: Para trabajadores sociales. 3. ed. Buenos aires: Humanitas, 1972. 335

AZEVEDO, Isabela. Descaso no trato com turistas. Caderno Brasília, Brasília-DF, 07 junho de 2009

BAHL, Miguel. Eventos(Org.). A importância para o turismo do terceiro milênio. $1^{\mathrm{o}} \mathrm{ed}$. São Paulo: Roca, 2003.

BAHL, Miguel(Org.). Turismo: Enfoques Teóricos e Práticos. São Paulo: Roca, 2003.

BAHL, Miguel(Org.). Mercado Turístico - Áreas de Atuação. São Paulo: Roca, 2003

BENI, Mário Carlos. Análise estrutural do turismo. 7a ed. São Paulo: SENAC, 2002

BENI, Mário Carlos. Análise estrutural do turismo. 12a ed. São Paulo: SENAC, 2007

BEATRIZ e MILONE, Paulo (Orgs.) Turismo teoria e prática. São Paulo: Atlas. pág. 223231.

BORBA, Gilson Z. Textos diversos sobre Gestão Estratégica de EmpreendimentosTurísticos do curso de especialização em Gestão de Negócios em Turismo, realizado pelo CET-UNB. Brasília: apostila didática, 2008.

BRAGA, Débora Cordeiro. Turistas de negócios na cidade de São Paulo: Teoria versus a realidade. Disponível: http://www.unisantos.com.br/pos/revistapatrimonio/artigos.php? cod=109\&bibliografia $=\mathbf{1} \&$ acesso $09 / 12 / 08$

SANTANA, Ivana Rabelo. Brasília. A Capital Brasileira dos Eventos, Brasília: Monografia

- UnB/CET, 2002 
BRASÍLIA CONVENTION \&VISITORS BUREAU. Perfil do Turismo e o setor de eventos no Distrito Federal. Brasília, 1996

BRITTO, Janaina; FONTES, Nena. Estratégias para eventos - Uma ótica do Marketing e do Turismo. São Paulo: Editora Aleph, 2002. 210p.

CAMARA LEGISLATIVA DO DISTRITO FEDERAL. Turismo como fator de desenvolvimento econômico para o Distrito Federal. Brasília, 1999.

CARVALHO, Alex Moreira; MORENO, Eleni; BONATTO, Francisco Rogério de O. ; SILVA, Ivone Pereira. Aprendendo Metodológia Científica. São Paulo: O Nome da Rosa, $2^{\mathrm{a}}$ edição, 2001.

DENCKER, Ada de Freitas Maneti. Métodos e Técnicas de Pesquisa em Turismo. São Paulo: Futura, 2001.

DESCARTES, R. Discurso do método. Rio de Janeiro. São Paulo, 2003.

DIAS, Reinaldo. Introdução ao Turismo. São Paulo: Atlas, 2008. 177p.

DIAS, Reinaldo. Fundamentos do Turismo. São Paulo, 2003

DUARTE, Valdir Vieira. Administração de Sistemas Hoteleiros: Conceitos básicos. $3^{\mathbf{a}}$ ed. São Paulo: Senac, 1996.

EHRLICH, Bruce e DREIER, Peter. The tourist city. Morrisvelle - USA: Yale University Press, 1999. $490 \mathrm{p}$.

FACHIN, Odília. Fundamentos de metodologia. São Paulo: Saraiva, 2001.

GOODE, William Josiah; HATT, Paul Kitchener. Métodos em pesquisa social. 5. ed. São Paulo: Companhia Editora Nacional, 1975. 488 p.

GOELDNER, Charles; ROTCHIE, J.R Brent; MCINTOSH, Robert. Turismo: Princípios, Práticas e Filosofias. Porto Alegre: Bookman, 2002.

KOTLER, Philip; HAYES, Tom; BLOOM, Paul. Marketing de services profissionais Estratégias inovadoras para impulsionar sua atividade, sua imagem e seus lucros $-2^{\circ}$ edição. Barueri-SP: Manole, 2002. 512 p. 
LICKORISH, Leonard J. e JENKINS, Carson L. Una introducción al turismo. Madrid: Síntesis, 1997. p.74

MADER, Helena. Pecados do Plano. Correio Braziliense, Brasília- DF, 01 março de 2009.

MORAES, Claudia. 1999. “Turismo segmentação de mercado: um estudo introdutório". In: ANSARAH, Marilia (org.). Turismo segmentação de mercado. São Paulo: Futura. pg. 13-33.

MOESCH, Martini Marutschka. Produção do Saber Turístico. $2^{\mathbf{a}}$ ed. São Paulo: Editora Contexto, 2002, p.41.

NISHIMURA, Jorge. Planejamento de um hotel voltado para negócios. In: LAGE, 2000.

PÁDUA, Elisabete. Metodologia da Pesquisa : abordagem teórico-prática. São Paulo: Papirus, 2002.

PERES, Adoniran. Trade comemora $7^{a}$ posição do Brasil no ranking da ICCA. Jornal de Turismo, Brasília, 25 a 31 de maio de 2009.

PINDYCK, Robert S; RUBINFELD, Daniel L. Microeconomia. 6. ed. São Paulo: Prentice Hall, 2006. 641 p.

RIELLA, Renato. Brasília já é feita por Brasilienses. Revista Veja - Informe publicitário, Brasília, DF, Ed. 2079.

SCHLUTER, Regina G. Metodologia da Pesquisa em Turismo e Hotelaria. São Paulo: Editora Aleph, 2003. 192 p.

SWARBROOKE, John. Turismo sustentável. Volume V. Trad. Saulo Krieger. São Paulo: Aleph. 2000.

TEIXEIRA, Aníbal. Marketing das Cidades: Atraindo empresas, turistas e negócios para sua cidade. São Paulo: Faculdade Internacional de Ciências Empresariais, 2002. 207 p.

TRIOLA, M.F. Introdução à estatística. Livros Técnicos e Científicos. Rio de Janeiro: Editora S.A, 1985. 
VERGARA, Sylvia. Projetos e relatórios de pesquisa em administração. São Paulo: Atlas, 2007.

VEIGA, Anna Paola. Brasília amanhã - Uma nova cara, sem mudar a estrutura original. Revista Foco, Brasília, Edição Especial, 2009.

\subsection{Mídias e endereços eletrônicos consultados:}

- Pesquisa Perfil do Turista de Brasília disponível em:

http://www.cet.unb.br/index.php?

option=com_content\&task=blogcategory\&id=16\&Itemid=37 - Acesso em 10/05/2009

- Informações sobre a cidade de Brasília

http://www.gdf.df.gov.br/045/04501018.asp

Acesso em 10/04/2009

- História da origem dos eventos disponível em:

http://pt.wikipedia.org/wiki/Turismo_de eventos

http://www.desvendar.com/especiais/historiadoturismo/introducao.asp

\section{$\underline{\text { Acesso em 15/12/2008 }}$}

- Entrevista Presidente da BrasíliaTUR César Gonçalves disponível em:

http://cetunb.tempsite.ws/index.php?option=com_content\&task=view\&id=502

Acesso em 15/12/2008

- Informações sobre turismo de eventos e negócios disponível em:

http://www.pr.gov.br/turismo/turismo_tipo_eventos.shtml?turistas

http://www.fbcevb.com.br

http://www.iccaworld.com

http://www.fbcevb.com.br/eventos.asp 
http://www.braztoa.com.br

Acesso em 15/04/09

http://www.abeoc.org.br/200801221736.php acesso em 28 de junho de 2009

MINISTERIO DO TURISMO, Segmentação do turismo disponível em:

http://www.mda.gov.br/saf/arquivos/0708519758.pdf acesso em 09/04/09

\section{- Informações sobre a infraestrutura de Brasília disponível em:}

http://www.setur.df.gov.br/

http://www.brasiliaconvention.com.br/

http: //www.elitearte.com.br/

http://www.jornaldeturismo.com.br/noticias/df/24727-brasiliatur.html

Acesso em 15/04/09

http://www.panrotas.com.br/noticia-turismo/gente/brasiliatur-tem-novo-presidente-e-novosdiretores_47641.html

http://www.hoteliernews.com.br/HotelierNews/Hn.site.4/NoticiasConteudo.aspx?

Noticia $=44165 \&$ Midia $=1$

Acesso 30 de maio de 2009

http://www.skyscrapercity.com/showthread.php?t=511341 acesso em 06 de junho de 2009

http://www.metro.df.gov.br/ acesso em 06 de junho de 2009

http://www.infraero.gov.br/aero_prev_home.php?ai=60

http://www.hotelinsite.com.br/cidades/brasilia.html

http://www.revistafator.com.br/ver_noticia.php?not=23643

Acesso em 08 de junho de 2009

Fotos e informações sobre os novos projetos de Brasília disponível em:

http://www.skyscrapercity.com/showthread.php?t=698940

Acesso em 7 de maio de 2009 
Pesquisa Indicadores Econômicos para o planejamento do turismo no Distrito Federal disponível em: www.cet.unb.br acesso em 05 de maio de 2009

Pesquisa do Perfil e da Satisfação do Turista de Lazer e de Negócios em Brasília disponível em: www.cet.unb.br acesso em 05 de maio de 2009 


\title{
7. APÊNDICE
}

\subsection{Instrumento de Coleta de Dados}

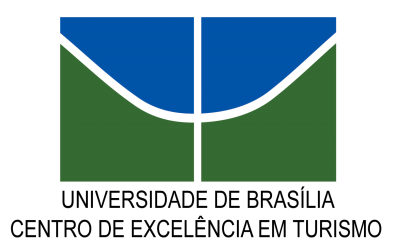

\author{
Aluno: Weider Daniel Lemes \\ QUESTIONÁRIO PARA PESQUISA DO CURSO DE GESTÃO DE NEGÓCIOS EM \\ TURISMO DO CET - CENTRO DE EXCELÊNCIA EM TURISMO
}

(PROJETO DE FINAL DE CURSO)

\section{1. Órgão ou empresa em que trabalha:}

2. Grau de Escolaridade: $1^{\circ}$ grau ( ) $2^{\circ}$ grau completo ( ) $2^{\circ}$ grau incompleto ( ) $3^{\circ}$ grau incompleto ( ) $3^{\circ}$ grau completo ( ) pós graduação ( )

3. Área do trade que atua: Órgão Público ( ) Agência de Viagem ( ) Hotel ( ) Locadora de carro ( ) Companhia aérea ( ) Agência de receptivo ( ) Universidade ( ) Ong ou associação ( ) Empresa de eventos ( )

4. Que tipo de turista Brasília mais recebe, em sua opinião? Turista de negócios ( ) turista de Eventos ( ) Turista de negócios e eventos ( ) Turista Cívico e de arquitetura ( ) Turista místico e religioso ( ) Turista Cultural ( )

5. Hoje, em sua opinião, qual a principal deficiência na infraestrutura de eventos de Brasília? Transporte deficitário ( ) Poucos Centro de convenções ( ) Número de leitos insuficientes ( ) Espaços para feiras e exposições deficitário ( ) Falta mão de obra especializada ( ) Trânsito ( ) falta de atrativos turísticos ( ) Gastronomia ( )

6. Em sua opinião qual a principal vocação turística de Brasília? Turismo de eventos ( ) Turismo de negócios ( ) Turismo de negócios e eventos( ) Turismo cívico e de arquitetura ( ) Turismo místico ( ) Turismo religioso ( ) Turismo cultural ( ) 
7. Você acredita que o trade Turístico em Brasília (Agências de Viagens e Eventos Hotéis - Pontos Turísticos em Brasília e Atrações turísticas no entorno de Brasília) trabalha de forma integrada? $\operatorname{Sim}($ ) Não ( )

8. Em sua opinião, qual principal dificuldade ou deficiência para que Brasília se destaque como destino turístico no Brasil? Falta de divulgação ( ) Falta de infraestrutura adequada ( ) Falta de estratégias para se posicionar ( ) Não explorar a principal vocação turística da cidade ( ) Falta de atrações turísticas de lazer e entretenimento ( ) Atendimento ( ) falta de integração do trade ( ) NDA ( )

Obrigado por sua participação na pesquisa! 